NBER WORKING PAPER SERIES

\title{
WELFARE AND THE WELL-BEING OF \\ CHILDREN: THE RELATIVE \\ EFFECTIVENESS OF CASH AND \\ IN-KIND TRANSFERS
}

Janet Currie

Working Paper No. 4539

\section{NATIONAL BUREAU OF ECONOMIC RESEARCH \\ 1050 Massachusetts Avenue \\ Cambridge, MA 02138 \\ November, 1993}

I would like to thank Anne Pebley, James Poterba and Duncan Thomas for useful comments and discussions. Vandy Howell and Jodi Fingerman provided excellent research assistance. Financial support from the National Science Foundation under grant number SES-9122640, and from the National Bureau of Economic Research's Olin Fellows Program is gratefully acknowledged. This paper is part of NBER's research program in Labor Studies. Any opinions expressed are those of the author and not those of the National Bureau of Economic Research. 
NBER Working Paper \#4539

November 1993

\title{
WELFARE AND THE WELL-BEING OF \\ CHILDREN: THE RELATIVE \\ EFFECTIVENESS OF CASH AND \\ IN-KIND TRANSFERS
}

\begin{abstract}
Cash transfers to families with children are increasingly being restricted to parents who work, while families of non-working parents are receiving a progressively larger share of their benefits in kind. This paper provides an evaluation of the empirical evidence regarding the effects of in-kind and cash transfer programs on the children who are their intended beneficiaries. A distinction is made between in-kind transfer programs, such as the Food Stamp Program, that provide transfers to families that are earmarked for certain purposes, and programs such as Medicaid that provide specific services directly to children. Although the evidence is incomplete, it suggests that in-kind programs have stronger effects on children than cash transfers, and that programs that target specific benefits directly to children have the largest positive effects.
\end{abstract}

Janet Currie Department of Economics University of California, Los Angeles

405 Hilgard Avenue Los Angeles, CA 90024 and NBER 


\section{Introduction}

Although the public identifies the term "welfare" with cash transfers to single mothers under the Aid to Families with Dependent Children program (AFDC). cash transfers are increasingly being restricted to parents who work. The norworking poor are receiving a progressively larger share of their benefits in $k$ ind (Moffitt, 1992). In a world in which governments could always identify the intended beneficiaries and issues of intra-household resource allocation did no: arise, in-kind transfers to poor families would be an inefficient way to increase the well-being of poor children. The "first-best" solution would be to allow families on welfare to choose the basket of goods that best suited their needs. In reality, it is necessary to design welfare programs that discourage those outside the targeted population from applying. Nichols and Zeckhauser (1982) show that if governments can identify goods that are valued more highiy by the deserving poor than by potential "imposters", then providing these benefits in kind is a more efficient way to transfer resources than providing cash, because fewer resources will be directed to imposters. Besley and Coate (1992) provide a similar analysis of requirements that welfare participants work. These papers provide a theoretical justification for restrictions on cash weifare and for the growing emphasis on in-kind transfers. The literature on intrahousehold resource allocation further suggests that policy makers should be concerned with how resources are utilized within the family.'

This paper provides an evaluation of the empirical evidence regarding the effects of 8 large federal cash and in-kind transfer programs on the children who are their intended beneficiaries. It is convenient to divide in-kind transfers into two groups: Those that provide transfers to the families of poor children that are earmarked for certain purposes (e.g. food stamps), and those that provide specific services directly to children (e.g. Medicaid). The evidence reviewed here suggests that in-kind programs have stronger effects on children than cash transfers, and that the more narrowly targeted the program, the iarger

1 For example. Thomas (1993) discusses the effects of allocating resources to mothers rather than to fathers. 
the effects.

The first part of the paper provides an overview of the major fecieral welfare programs that benefit children and documents the trends towards in-kind benefits, and towards restrictions on cash transfers. Measures of child welibeing are also discussed. The second section discusses the evidence regarding the effects of cash transfers on children. In-kind transfers are analyzed in Part 3, and the relative efficacy of earmarked vs. more narrowly targeted programs is discussed. Conclusions appear in Part 4.

\section{Background}

a) An Overview of the Federal Welfare System²

Figure 1 shows the evolution of federal expenditures on the eight largest welfare programs benefitting children. Administrative costs are exciuded whenever possible, as are state matching contributions for AFDC and Medicaid. Expenditures (in real 1990 dollars) have been divided into cash transfers and two types of in-kind transfers: "Earmarked" programs include food stamps and housing assistance, while "targeted" programs include Medicaid, Head start, the National School Lunch Program (NSLP), and the Special supplemental Feeding program for Women, Infants, and Children (WIC). The figure shows the remarkable increase in in-kind relative to cash benefits: While cash transfers grew only $18 z$ between 1975 and 1990, in-kind transfers shot up 518. Earmarked programs make up the bulk of expenditures on in-kind programs, but the two types of in-kind programs have shown roughly equal growth over time.'

Figure 2 provides a more detailed breakdown of the evolution of expenditures in each of the three categories, while Table 1 gives the amounts spent in 1975, 1980 and 1990. Table 2 provides information about caseloads in

${ }^{2}$ Unless otherwise noted, the information in this section comes from the U.S. House of Representatives (1991, 1992).

It is interesting to compare these outlays on children to federal expenditures on the elderly. In 1990, the federal government spent $\$ 1,020$ per child under 18 compared to $\$ 11,350$. per elderiy person (U.S. House of Representatives, 1992). The largest component of spending on the elderly was Social Security which came to $\$ 193$ billion. 
these three years. The rest of this section provides background information about the programs described in these Tables.

i) Cash Transfers

As shown in Figure 2 and Table 1, cash transfers can be divided into expenditures on AFDC, and outlays under the Earned Income Tax Credit. AFDC was originally authorized under the Social Security Act of 1935 as a federal-state matching entitlement program that would provide assistance to fatherless children." As of October 1, 1990, states are also required to offer an AFDC Unemployed Parent (AFDC-UP) program to two-parent families in which the principle earner is unemployed."

AFDC is administered at the state level within federal guidelines - - states choose the need and payment standards that determine eligibility, set income ard asset limits, and choose benefit levels. As a result, program characteristics vary widely from state to state. For example, as of January 1991, the maximum monthly AFDC grant for a one-parent family of 4 persons varied from $\$ 124$. in Alabama to $\$ 891$. in Alaska. By way of comparison, the federal poverty line for a family of 4 persons was $\$ 13,942$. On average the federal government pays 548 of benefit costs, as shown in Table 1 .

Figure 2 shows that expenditures on the AFDC program have been deciining gradually over time. In view of the fact that the maximum AFDC benefit for a family of four in the median state fell by 338 between 1975 and 1990, and the decline in the AFDC caseload documented in Table 2, it is remarkable that total expenditures have not fallen further. Since two, 2-person families are more expensive than a single 4-person family, these figures may reflect a shift in the composition of the caseload towards smaller families.

Table 1 shows that the slack in AFDC growth has been taken up by growth in expenditures on the Earned Income Tax Credit (EITC), which doubled between 1975 and 1990. Table 2 shows that the growth in expenditures was accompanied by a

- The fact that it is an entitlement program means that anyone who meets the eligibility criteria is entitled to receive benefits.

s Only 58 of AFDC families qualified under this program in 1990. 
doubling of the caseload over the same period. The EITC was introduced in 1975 as a means of granting tax zelief to low-income tax payers. In 1992, the maximum EITC was $\$ 1,324$. for tax payers with one qualifying child and $\$ 1,384$. for tax payers with any additional qualifying children. The EITC begins to be phased out for tax payers with adjusted gross income (AGI) above $\$ 11,840$. and is completely phased out for tax payers with AGI greater than $\$ 22,370$.

Because it is administered through the tax system, the EITC is not usually viewed as a welfare program. However, unlike most tax credits, the EITC is "refundable", that is, if the amount of the credit exceeds the tax-payer's federal income tax liability, then the difference is refunded. Table 1 shows that in fact most EITC expenditures were outlays of this kind rather than foregone tax dollars. The EITC differs from traditional cash welfare programs primarily because the majority of recipients work, and benefits are available to all kinds of families.

\section{ii) Earmarked Programs}

As discussed above, expenditures on earmarked programs can be divided into expenditures on the Food Stamp Program (FSP) and outlays for housing assistance. The Food Stamp Program grew out of efforts to transfer surplus agricultural commodities to the needy during the Great Depression. These programs had been formalized and extended to all counties by 1973 (Clarkson, 1975). Food stamps are issued in the form of booklets of coupons which may be used to purchase all foods except alcohol, tobacco, and hot foods "intended for imediate consumption." In contrast to AFDC, Food Stamps are available to all families who meet federally determined income-eligibility requirements, though AFDC recipients are automatically eligible. Interactions between the FSP and AFDC provide the only source of state-to-state variation in food stamp benefits - Fsp income is reduced by $\$ .30$ for every dollar of countable income (including AFDC benefits), once certain disregards are applied. ${ }^{\circ}$

Table 1 indicates that expenditures on the Food stamp program grew by $50 \%$ between 1975 and 1990, while Table 2 shows that caseloads rose only 25\%. Hence,

\footnotetext{
"See U.S. House of Representatives (1992) for details.
} 
the increased generosity of food stamp benefits made up part of the loss in cash transfers for AFDC households. However, Figure 3 illustrates the fact that in 1992, even combined AFDC and food stamp benefits were not high enough to bring families up to the poverty level in most states.

Housing assistance has been provided since 1937 under the auspices of the Department of Housing and Urban Development (HUD). In contrast to AFDC and food stamps, housing assistance is not an entitlement: When funds allocated to the program run out, people who are eligible must be wait-listed. It is estimated that about half of federal expenditures on housing assistance directly benefit children while the elderly are the other large group of beneficiaries. $T h e$ federal government offers mortgage assistance to low-income rural households, but most expenditures are on rental assistance programs.

The major forms in which rental assistance is offered are: 1) low-rent public housing, 2) Section 8 new construction/substantial rehabilitation, and 3) Section 8 existing housing. Low-rent public housing is what most people think of as "public housing". The Section B programs were established by the Housing and Community Development Act of 1974. Under the new construction/rehabilitation part of the program, the federal government subsidizes the rents of apartments brought into the stock by private developers. The Section 8 existing housing program provides rent subsidies to families who find an apartment of their own choosing, as long as the rent is below the "Fair Market Rent" established by HUD, and the unit meets minimum quality standards. Rental assistance typically reduces a family's rental payments to 308 of its income, after deductions for certain expenses are taken into account.

The Congressional Budget office estimates that since 1982, over two-thirds of new authorizations for rental housing assistance were for section 8 programs (Pedone, 1988). The main rationale for this shift in policy is that it is cheaper to house a family in an existing unit under a voucher program than it is to build new public housing units (Apgar, 1990). Hence, more families can be served for the same budget outlay. Tables 1 and 2 show that both outlays on housing assistance and the caseload grew by roughly 668 between 1975 and 1990 . 


\section{iii) Services Targeted Directly to Children}

Finally, turning to services targeted directly to children, Figure 2 indicates that the largest program of this kind is Medicaid. The Medicaid program provides health insurance to eligible poor families and to the aged, blind, and disabled. It was created in 1966 as a federal-state matching entitlement with the stated goal of eliminating financial barriers to medical care. Table 1 shows that expenditures on children account for a relatively small share of total Medicaid expenditures: The average expenditure on an AFDC child is $\$ 682$. compared to $\$ 5928$. for an aged person and $\$ 1290$ for an AFDC adult (U.S. House of Representatives, 1991). Notwithstanding children's relatively small share of Medicaid expenditures, Medicaid is the single most important health insurance program for poor children, accounting for over 558 of public expenditures on child health.

States are required to offer Medicaid coverage to AFDC recipients and to AFDC-UP families and until recent extensions of coverage to other groups, there was a very close linkage between AFDC recipiency and Medicaid eligibility. However, evidence that many children and pregnant women were not receiving adequate preventive care led Congress to begin extending Medicaid coverage for pregnant women and children in 1984 . States are now required to cover all pregnant women and children under 6 with family income less than 2338 of the federal poverty line, regardless of family structure.' As of July 1, 1991, states were also required to cover all children born after september 30, 1983 whose family incomes were less than 1008 of the federal poverty line.

Tables 1 and 2 show that expenditures on children under the Medicaid program have risen dramatically since 1975, although caseloads grew only slowly. This increase in Medicaid costs reflects an increase in the cost per visit that is also occurring in the non-Medicaid population (Newhouse, 1992). The relatively stagnant caseload may reflect low takeup rates among newly eligible children.

'The coverage of pregnant women is limited to services related to the pregnancy. 
Other large programs that target services directly to children inciude school nutrition programs, WIC, and Head start. ${ }^{*}$ Figure 2 indicates that relative to the growth in expenditures on "earmarked" programs and on Medicaid, there has been only modest growth in these three targeted programs: Total expenditures on the School Lunch Program, WIC and Head start increased only 20 between 1975 and 1990. However, Table 1 shows that this aggregate masiks considerable variation in individual program trends. For example, expenditures on WIC doubled, while outlays on Head start grew 608 , and expenditures on the NLSP actually fell 188 .

The federal government supports 7 programs that provide meals or monthly food supplements to low-income children. The largest are the National School Lunch Program (NSLP), the School Breakfast Program (SBP), and WIC. The NSLP and SBP are entitlements that operate by reimbursing schools for each meal served. WIC is funded by appropriation and the size of each year's appropriation limits the number of people that can be served.

The NSLP was begun in 1946 in response to national concern about the fact that one-third of World War II draftees suffered nutrition-related deficiencies that made them unfit for service. The NSLP is by far the largest of the child nutrition programs: In 1981, lunches were served to approximately 25 million students in 988 of the public schools -- enough to feed 608 of all students attending public schools (Radzikowski and Gale, 1984a). However, Table 2 shows that the total number of children served had fallen more than 508 by 1990. School lunches are provided free to children with family incomes less than 1308 of the federal poverty line, and are subsidized if the family income falls between 130 and 1858 of the poverty line. Table 2 shows that the number of children receiving free lunches has remained relatively constant over time at about 10 million, while the number receiving reduced-price meals declined $50 \%$ between 1975 and 1990, from 27 to 13 million.

The School Breakfast program was instituted in 1966 . It serves far fewer

'See Jones (1990, 1992) for further information about school nutrition programs, and WIC. 
children than the lunch program: In 1981, about 4 million breakfasts were served in 33,000 schools, enough to feed about 108 of the public school student bocy." Participants in the SBP tend to be poorer than participants in the NSLP -- with the result that the majority of school breakfasts have always been served free.

The WIC program provides nutritional counseling and food suppierrents =0 pregnant and lactating mothers and their infants as well as to low-income children up to age 5. It is currently operated out of some 8,330 sites. The law requires that the WIC program provide foods containing protein, iron. calcium, vitamin A, and vitamin C. Food packages must be appropriately tailozed to meet the needs of each category of recipient. ${ }^{10}$ In fiscal year 1991, the average monthly WIC package was valued at $\$ 31.67$.

WIC Participants must have family incomes less than 1858 of the poverty line, (though states may set income thresholds as low as 1008 of the poverty line), and must be certified to be nutritionally "at risk". 11 Participants must be re-certified at intervals in order to continue in the program. Table 2 indicates that the WIC caseload shot up 4008 between 1975 and 1990 , far outstripping the increase in expenditures discussed above. WIC currently serves an estimated 608 of those eligible. According to the Congressional Budget Office, it would have cost $\$ 3.75$ billion, or 448 more than that year's appropriation, to serve all those who were eligible in 1992.

Head Start is a federal-local matching grant program that aims to improve the learning skills, social skills, and health status of poor children so that they can begin schooling on an equal footing with their more advantaged peers. Federal guidelines require that 908 of the children served be from families with incomes below the federal poverty Iine. Given that there are over 1300 Head start programs (Hayes et al., 1990), all administered at a local level, there is

'These numbers have remained relatively constant over time.

:0 The categories are children 0 to 3 months of age, 4 to 12 months, women and children with special dietary needs, children from 1 to 5 , pregnant and nursing mothers, and postpartum non-nursing mothers.

11 Evaluation of WIC is complicated by the fact that providers do not use uniform criteria for certifying nutritional risk. 
a great deal of variation in program content.

Begun in 1964 as part of President Johnson's "War on Poverty", Head Start is one element of that program that has enjoyed great public and bi-partisan support. Former President Bush and President Clinton both pledged to increase federal funding so that all eligible children may be served. In 1992, 622,000 children, roughly 28 of eligible 3 to 5 year olds, were served at a cost of $\$ 2.2$ billion (Stewart, 1992). Table 2 shows that this represents an increase in the caseload of 698 between 1975 and 1990 .

In summary, cash transfers are increasingly being restricted to parents who work. Parents who do not, are receiving an increasing proportion of their assistance in the form of in-kind benefits. However, only a relatively small share of these benefits are in the form of specific services provided directly to children. The lion's share are provided to families in the form of certificates that must be spent on food or housing.

b) Measures of Child Well-Being

Despite the fact that the programs discussed above are designed to benefit children, there has been remarkably little research aimed at assessing the direct effects on child well-being. Much of the difficulty lies in finding data sets with information about both welfare participation and child outcomes. Ideally, one would like to examine a range of outcomes since the effects of participation are likely to be complex. For example, while Medicaid participation might be expected to improve children's health, it may also have positive effects on schooling attainment if poor health would otherwise have impaired the child's performance. This section describes the three classes of outcomes that are the focus of this review: Measures of health, measures of cognition and schooling attainment, and measures of long-run social competence.

i) Measures of Health Status

Infant and child mortality rates are perhaps the most objective and least controversial measures of children's health status. The infant mortality rate is defined as the number of babies born alive who die before reaching age 1 . At 10 per 1000 , the U.S. infant mortality rate is higher than that of any other 
industrialized country, and African-American rates are twice as high as white rates (Danzinger and Stern, 1990). A closely related measure of infant health is birthweight -- in 1980 infants less than 2500 grams accounted for less than 78 of all births, but 608 of infant deaths (U.S. House of Representatives, i992). Gestational age is also used as a measure of neonatal health, but is subject to a great deal more measurement error than birthweight.

Height-for-age is an anthropometric measure of the health and nutritional status of older children (for babies the equivalent measure is length-for-age). Physical anthropoligists have concluded that ethnic differentials in these measures are relatively minor for young children, although they become more important after puberty. Since growth varies systematically with age and gender, heights are usually standardized using guidelines from the National Center for Health Statistics. ${ }^{32}$ The incidence of low height-for-age (stunting) is much greater among poor than among non-poor children. For example, a 1983 study carried out by the Massachusetts Department of Health found that 9.88 of preschool children in Massachusetts had a height-for-age below the 5 th percentile of the NCHS standards (Massachusetts Department of Health, 1983).

Nutritional status can also be assessed using information about the nutrients "available" in a family's usual diet, individual nutrient intakes, or biochemical tests. Low-income American children are at risk of iron and zinc deficiencies, and often lack vitamin C. For example, Devaney, Haines, and Moffitt (1989) found that 20.68 of 1 to 2 year old children in low-income households suffered iron anemia compared to 6.7 of 1 to 2 year olds from higher income households. These deficiencies have been linked to growth retardation, lethargy, impaired immune status, and learning problems.

A third class of measures deal with the child's utilization of medical services. Measures such as the number of doctor visits for iliness are problematic since they are affected both by illness and by the propensity to utilize care. Visits for preventive care provide cleaner measures of utilization. Prenatal care is another important type of preventive care.

32 See Currie and Thomas (1993b) for further details. 
Prenatal care that is adequate in terms of timely initiation and the total number of visits has been shown to significantly reduce the risk of low birthweight and infant mortality (Institute of Medicine, 1985).

ii) Test Scores and Schooling Attainment

Academic achievement is a very important determinant of a child's success in our society: Each additional year of high school is estimated to raise future wages by as much as $B \& .{ }^{13}$ It is not surprising then, that many tests of academic achievement have been developed. These tests are controversial: African-Americ is obtain poorer scores than whites, and depending on the test. girls may outperform boys or vice-versa. And it is not clear that these tests are ultimately good predictors of academic success, once measures of a child's background are adequately controlled for. More direct measures of academic attainment include whether the child has ever taken remedial courses or been retained in grade. There is a great deal of evidence which suggests that children who lag behind their peers even at early ages are at higher risk of eventually dropping out of highschool (Ensminger and slusarcick, 1992).

\section{iii) Longer-Term Measures}

The ultimate measure of the success of a welfare program is the long-run situation of children whose families participated. Are they less likely to become pregnant as teenagers, to be unemployed, or ultimately to have their own children participate in welfare programs? It has proven extremely difficult to answer this question because it is difficult to sort out the effects of welfare participation from the effects of family background and community characteristics.

\section{Part 2: Do Cash Transfers Benefit Children?}

a) Effects of $A F D C$

Most research about the effects of AFDC on children, focuses on the question of whether daughters of women who participate in AFDC are themselves more likely to participate (c.f. Gottschalk, 1990). Critics of the welfare system, point to the intergenerational transmission of welfare dependency as

"See Angrist (1990) for a recent estimate. 
evidence that parental welfare participation actually harms poor children by affecting their aspirations (c.f. Murray, 1984). However, this argument overiooks the fact that women whose mothers were on AFDC are morewlikely than other women to be on AFDC simply because the children of the poor are more iikely to be poor.

Zimmerman and Levine (2993) test the hypothesis that AFDC has no additional negative effect using data from the original National Longitudinal Surveys and the National Longitudinal survey of Youth. They regress the daughter's participation in AFDC on measures of maternal participation, maternal income, and other background variables. Since both maternal AFD participation and income are to some extent choices and may be measured with error, they propose the following instrumental variables (IV) technique: Instrument AFDC participation using maximum benefit levels in each state, and instrument income using the Duncan index of the mother and father's occupations. "They find that maternal AFDC participation has no statistically significant effect on the daughter's probability of participating, once maternal income is controlled for.

This IV scheme implicitly assumes that women do not migrate in response to $A F D C$ benefits and that occupational choices are predetermined to a greater extent than incomes are. The first assumption is reasonable in light of empirical evidence that migration flows in response to benefit levels are very small (Moffitt, 1992). The second is perhaps less defensible. Still, zimmerman and Levine's paper is the first to attempt to instrument both participation and income in a reasonable way and it suggests that it is poverty and not maternal welfare receipt that creates welfare mothers.

These results suggest that maternal welfare participation does not encourage teenage pregnancy and child-bearing." Although the teen birthrate

14 The Duncan index is a linear combination of the median earnings and education associated with an individual's occupation.

13 Concern is often expressed that AFDC has contributed to the problem by undermining family values -- by supporting single parenthood and allowing teenagers to set up housekeeping on their own once they have a child. The Family Support Act of 1988 eliminated some of the perverse incentives of the system by requiring all states to establish AFDC-UP programs, and to make more strenuous 
has fallen over time (from 90 births per 1000 in 1955 to 54 per 1000 in 1988 ). out-of-wedlock births to teenagers increased from 15.1 to 37 per 1000 women aged 15 to 19 over the same period (U.S. DHHS, various years). The fact that the rate of out-of-wedlock pregnancy has increased while the AFDC benefit level has continued to fall also indicates that there is no simple relationship between the two. Studies that have examined this question directly reach the same conclusion. For example, neither Moore and Caldwell (1977), nor Ellwood and Bane (1985) were able to find any consistent effect of state benefit levels on the probability of a teen pregnancy. ${ }^{16}$

There has been comparatively little research linking maternal AFDC participation to other child outcomes, but the empirical issues are the same. First, it is necessary to control for some measure of income as well as for AFDC status since otherwise the estimated effects of participation are likely to reflect the relative poverty of AFDC mothers. Second, within the group of poor women, one would like to control for the endogeneity of AFDC status. Blank and Ruggles (1993) show that only 608 of eligible women actually take-up welfare benefits. Those who do are likely to differ from those who do not in many unobservable respects.

Hill and O'Neill (1992) find that, when IV methods are used to control for AFDC status, AFDC participation has no effect on children's scores on a standardized test of vocabulary, conditional on income. They do not control for the potential endogeneity of income. Currie and Cole (1993) use data from the 1979 to 1988 waves of the National Longitudinal Survey of Youth (NLSY) to examine the effect of AFDC participation during pregnancy on the utilization of prenatal care and birthweight. They attempt to control for selection into the AFDC program in two ways. First, they instrument AFDC participation using state-level variation in program characteristics. Second, they focus on the sample of

\footnotetext{
efforts to establish paternity and extract child-support payments from fathers.

16 Moore and Caldwell also find no effect for the rate at wich A.FDC applications were accepted. However they did find that the availability of family planning clinics had a significant negative effect on the probability of teen pregnancy.
} 
chiluren who are siblings and estimate models that control for fixed effects associated with each mother. This procedure "differences-out" any fixed materna? characteristics (such as lack of education) associated with program participation. Finally, they control for a measure of "permanent-ircome" on tre grounds that this is less subject to endogeneity bias than a measure of contemporaneous income. They do not find any significant effect of $A F D C$ participation on birthweight. Together, these studies suggest that income from $A F D C$ has much the same effect on children as family income from any other source.

\section{ii) The Effects of the EITC}

If it is difficult to identify the effects of cash transfers under tine $A F D$, identifying the effects of the EITC are even more formidable. The fundamental problem is that the amount of the credit depends only on the parents' earnings, and earnings are likely to reflect many unobserved factors relevant to child well-being. However, the EITC is in many respects similar to the "Negative Income Tax" (NIT), an income guarantee program that was subjected to exhaustive scrutiny through a number of large-scale social experiments, although it was never implemented. This section draws the parallels between the two programs, and discusses what can be learned about the effects of cash transfers from the NIT experiments.

Under a NIT, a family who earns no income is guaranteed a minimum level of income, 6 . Families with earnings, $\mathbf{Y}$, receive a payment $D$, where $D=0-t_{1} Y$. The quantity $B=0 / t_{1}$ is referred to as the breakeven level of income since workers who earn more than $\mathbf{B}$ receive no payments. If income is equal to the wage multiplied by hours worked, and workers face a tax rate $t$, then workers on the NIT earn $w(1-$ $\left.t-t_{1}\right)$ for every hour of work, whereas workers with incomes above $\mathbf{B}$ earn $\mathbf{w}(1-t)$. That is, workers on the NIT face a higher implicit tax rate than other workers. Hence, both the EITC and the NIT work through the tax system to increase the level and reduce the variance of income among the poor. However, the EITC differs from the NIT in that the EITC has no income guarantee, and lowers effective marginal tax rates for the poorest rather than raising them.

In order to investigate whether the NIT created significant work 
disincentives, the Office of Economic Opportunity under President Nixon authorized 4 large-scale social experiments. The first experiment, in New Jersey and Pennsylvania, lasted from 1968 until 1972 and involved 1.357 low-income couples. A rural experiment took place in Iowa and North Carolina from 1969 to 1973 and included 809 low-income rural families. A third experiment was conducted in Gary, Indiana between 1971 and 1974 and was composed of 1,780 African-American households, 598 of them female-headed. The largest experiment. which affected 4,800 families, was conducted in Seattle and Denver from 1971 to 1982.

The NIT experiments represented the first large-scale attempt to investigate social policy using a treatment and control design with random assignment. Treatments received an income guarantee level and a tax rate. The guarantees were usually expressed as a percent of the federal poverty line, and ranged from 50 to 2508 . The average payments in the Seattle/Denver experiment, for example, ranged from \$919. to $\$ 2031$. (1972 dollars) depending on the treatment group. By way of comparison, the poverty line for a family of 3 persons was $\$ 3,099$. The NIT experiments provide a unique opportunity to assess the effects of income transfers per se on the well-being of children in poor families.

In principle, the use of random assignment overcomes the problem of selection that is ubiquitous in the program evaluation literature, and allows the effects of the program to be identified through a simple comparison of treatments and controls. However, the NIT experiment was flawed in two respects. First, treatments and controls were randomly assigned only within income categories. Hence, the cell sizes available for treatment/control comparisons are very small. Second, controls were much more likely to leave the experiment than treatments. These two problems mean that much of the NIT data has been analyzed using conventional non-experimental methods and the results are sensitive to the way that problems of non-random selection into treatment groups and attrition are handled (Ashenfelter and Plant, 1990).

These problems may account for inconsistent findings across experimental 
populations and for econometric estimates that are at odds with those derived from simple comparisons of treatments and controls. For example, Kehrer and Wolin (1979) find that the mean birthweight of infants born to the treatment group in the Gary experiment was actually lower than the birthweight of the controls. Yet estimates from their structural model suggests that the infants of treatments had higher birthweights in 9 out of 12 maternal age groups. O'Conner, Madden, and Pringle (1976), examined the effect of the NIT on child nutrition using data from the rural experiment. Among subjects in North Carolina, they found positive and significant treatment effects on intakes of energy, calcium, phosphorus, iron, riboflavin and vitamin $C$. However, the treatment did not appear to have any significant effect in Iowa, a finding that the authors attribute to the relative poverty of the North Carolina sample.

The results from the rural and Gary experiments have also been used to examine the effect of the NIT on schooling attainment. Maynard and Crawford (1976) found that elementary school children from NIT families in North Carolina showed statistically significant improvements in attendance, performance on standardized tests, and grades. However, there were no effects for older children or for elementary school children in Iowa. Their results are reproduced in Table 3. Once again, this pattern of results is attributed to the fact that the children in North Carolina were much more disadvantaged than those in Iowa. Maynard and Murnane (1979) found that in the Gary experiment the NIT treatment had positive effects on the reading scores of younger children but that these effects were statistically significant only among children whose families had been in the program for 3 or more years.

Finally, in an analysis of data from the New Jersey experiment, Mallar (1977) found that teenagers whose parents were enrolled in a NIT plan were between 208 and 908 more likely to complete high school depending on the parameters of the plan. This group also completed one-third to one-and-a-half more years of education than their counterparts in the control group. However, Venti (1984) found only an 118 increase in the probability of completing highschool for youth in the seattle/Denver experiment. This lower estimate seems 
more probable in view of the relatively short duration of the experiments, and the many longterm factors (such as achievement in early grades) that have been linked to educational attainment. These results may also be related to the fact that, in all 4 experiments, youths in treatment households were less likely to be employed than controls (Robins, 1985).

These studies suggest that the relatively large income transfers made to poor families under the NIT had a positive effect on the nutritional status, and on the educational attainment of children, especially among the poorest families. However, the magnitudes vary so greatly from study to study that it is difficult to say how large these effects may be. Perhaps unsurprisingly, studies of the consumption effects of the NIT also suggest that families spent much of the subsidy on goods that may not have been directly related to the well-being of their children. For example, the NIT appears to have had a negative effect on the labor supply of married women ${ }^{17}$, and positive effects on housing expenditures and purchases of consumer durables (Robins, 1985; Michael, 1978 ). The NIT may also have increased the probability of marital dissolution, although this finding remains controversial (c.f. Cain and Wissoker, 1990; Hannan and Tuma, 1990).

\section{Part 3: The Eefectivenese of In-Kind Transfer:}

a) Earmarked Transfers

\section{i) Effects of the Food Stamp Program}

It would be surprising to find that the marginal propensity to consume food out of food stamp income differed from the marginal propensity to consume food out of cash income because 85 to 908 of participating households have food expenditures that exceed the value of their FSP benefits. Two experimental "cashout" programs have suggested that food stamp income is treated exactly like cash income. However, one of these took place in Puerto Rico where there was a thriving black market in stamps before the cashout (Moffitt, 1989), and the other

\footnotetext{
${ }^{17}$ No convincing evidence of a link between maternal employment and children's well-being has been found. See Blau and Grossberg (1990) and Desai et al. (1989)).
} 
affected only elderly households (Blanchard, 1982). Hence it is not clear that the results of these experiments can be extrapolated to mainland families with children.

on the other hand, non-experimental evaluations of the fungibility of food stamps among families with children are contaminated by the failure to properly control for the endogeneity of program participation. For example, Table 4 shows that FSP households purchase more nutritious food for home consumption than nonparticipating households', but it is not clear whether this is a cause or an effect of program participation -- It might be the case that families who participate care more about nutrition. Since the FSP is federally administered, all geographic variation in benefits comes from interactions between the AFDC program and the FSP. Many researchers have resozted to trying to identify IV models by finding characteristics of families that affect program participation without affecting food expenditures. Fraker (1990a) provides a review of this literature.

Fraker (1990b) is one of the few studies that attempts to lise tise geographic variation in FSP benefits to identify the effects of the program. He finds that in OLS regressions, participation in the FSP has a positive effect on 7 of 16 nutrients examined. When he instruments using maximum FSP benefits as one of the instrumental variables, the standard errors rise but the point estimates stay relatively constant. This result suggests that one might find positive and significant effects of the FSP given greater variation in benefit levels or larger samples.

The results of Korenman and Miller (1992) are also inconclusive. They use data from the National Longitudinal Survey of Youth to examine the effect of FSP participation during pregnancy on birthweight, the incidence of low bizthweight, gestational age, the incidence of prematurity, and mother's weight gain during pregnancy. They find a statistically significant effect of participation by women with incomes less than 508 of the poverty line on birthweight of first born

${ }^{18}$ These differences remain when observable characteristics of the household are controlled for. 
children in OLS regressions. However, they find no effect for children of higher birth order, or when they control for unobserved characteristics of the mother using fixed effects models. They also report that the height-for-age of children whose families received food stamps in the year prior to the survey is significantly lower than that of other children. These results highlight the importance of controlling for unobserved heterogeneity when evaluating the efficacy of social programs.

There are two intriguing hypotheses that have been advanced to explain why food stamp income might have a different effect on nutrient intakes than cash income. First, it is possible that households view FSP benefits as a more permanent source of income than other sources. Second, women with children may have higher marginal propensities to purchase food than men, and the female head of household may have more control of food Stamp coupons (which are likely to be issued in her name) than she has over the household's cash income. ${ }^{29}$ Neither theory has been subjected to an empirical test.

\section{ii) Effects of Housing Assistance}

Deficient housing can pose a hazard to children's health. For example. lead poisoning is three times more common among poor children than among non-poor children and is directly related to housing conditions. The risk of accidental death is also three times higher, and some of this increased risk may be due to hazards in the home (Starfield, 1985). In 1989, 188 of poor households $(2.2$ million households), lived in housing with severe or moderate physical problems compared to 78 of non-poor households. ${ }^{20}$ If housing assistance enables families in deficient housing to move to adequate housing, then it probably improves the

19 Some circumstantial evidence pertinent to this hypothesis comes from the washington state Welfare Reform Demonstration Program. AFDC recipients in demonstration counties had the option of choosing to receive their AFDC and Food stamp benefits in the form of a single consolidated check rather than continuing to receive food stamp coupons. Over 208 of these women opted to continue receiving the coupons.

20 Problems HUD classifies as severe include lack of basic plumbing facilities, serious heating breakdowns, and rat infestations. An example of a moderate deficiency, is the use of unvented gas, oil, or kerosene heaters as primary heating equipment. 
physical well-being of children.

However, little evidence is available on this question. A 1988 HUD study found that more than half of public housing households lived in projects that needed moderate to substantial rehabilitation just to meet HUD's own standards. The estimated cost of bringing these units up to standard would exceed $\$ 20$ billion 1986 dollars (Lazere et ai., 1991). Most voucher programs require families to locate a landlord willing to participate in the section 8 program, and to arrange with the landlord for inspections and repairs within a fixed period of time. One case study of 56 single mothers in eastern Massachusetts in 1985 and 1986, found that after waiting an average of 2 years to receive a certificate, 24 women returned them unused because they were unable to find housing that met program requirements within the allotted time (Mulroy, 1988). The remaining women were able to improve their housing situations. Data from the 1986 Freestanding Voucher Demonstration program indicates that 608 of eligible households participated and that 578 of the subsidy went towards increasing rental payments (Kennedy and Finkel, 1987). Hence, there is some evidence that voucher programs may decrease the number of participating households living in substandard housing. ${ }^{21}$

Unaffordable housing can also have harmful effects on children, by squeezing family budgets. Standards set by federal law define affordable housing as housing that consumes no more than 308 of a household's "adjusted" income. 22 In 1989, three quarters of poor households in the U.S. paid over 308 of their income for housing, and more than half spent over 508 (Lazere et al., 1991). Families on AFDC fare just as badly because in all but 7 states, the maximum AFDC benefit for a family of 3 is less than HUD's estimate of the "Fair Market Rent" for a two-bedroom apartment. For families in these circumstances, receiving housing assistance can effectively double the family's cash income. Meyer et al.

21 Contemporary voucher programs seem to have larger effects on rental payments than subsidies offered to families under the Experimental Housing Program. See Apgar (1990) for a discussion.

22 Adjustments include deductions for dependent children, handicapped or elderly family members, and for excessive health or child care costs. 
(1993) report that among low-income children attending a Boston clinic, those living in public housing or receiving rent subsidies are significantly less likely to suffer from iron anemia. This evidence is consistent with the evidence from the NIT experiments since it suggests that large cash transfers can improve the nutritional status of the poorest children.

Finally, in principle, housing assistance can affect children by influencing the parent's choice of neighborhood and schools. For example, Johnson (1986) found that recipients of housing allowances frequently moved to better neighborhoods, although they did not usually move to less segregated ones. However, it is very difficult to identify the effects of neighborhoods and schools because any relationship we observe between neighborhood characteristics and individual outcomes could reflect the characteristics of the individual or of his or her family that drew them to the neighborhood in the first place.

The Gautreaux program provides a "natural experiment" that sheds light on this issue. It grew out of a lawsuit filed in 1966 against the Chicago Housing Authority and HUD on behalf of public housing residents. The suit charged that the Chicago low-rent public housing program had been administered in a racially discriminatory manner. A consent decree established by the supreme court in 1976, created a unique demonstration program with the aim of reducing segregation in Chicago's public housing.

under the program, residents in public housing projects can apply for Section 8 housing certificates and move to private apartments. Some apartments are in predominantly white suburbs, while others are in the inner city. Although the persons admitted to the program are not a random sample of public housing residents ${ }^{23}$, the program assigns apartments in an approximately random manor since the apartment an applicant is offered depends on what the agency has available when the applicant reaches the top of the waiting 1 ist. Very few

23 Applicants are screened to make sure that they have paid their rent regularly, and that they have adequate housekeeping abilities. The program does not serve families with more than 4 children because few large housing units are available in the suburbs. In addition, the act of applying for an apartment in an unknown location may indicate that a person is strongly motivated to improve his or her circumstances. 
applicants turn down an offered apartment, because if they do, they are unlikely to be offered another. Hence, differences in outcomes between applicants assigned to the suburbs and those assigned to the city are likely to reflect true neighborhood effects.

Rosenbaum (1982) found that children of participants who moved to the suburbs attended schools that were superior in terms of smaller class sizes, and satisfaction with teachers and courses. On average, these children had better attitudes towards school, and suffered no permanent decline in grades or attendance. However, some children had trouble meeting higher academic standards in the suburbs and were placed in lower grades, lower tracks, or in remedial education.

The children in the original study were re-interviewed 7 years later (Rosenbaum (1992)). Unfortunately, only 598 of the original sample children, or 107 children, could be located, so the estimated program effects may be biased if there was differential attrition from the two groups. Still, the results are striking: Children who had moved to the suburbs were 158 less likely to have dropped out of school, 168 more likely to be in a college-track program, and 348 more likely to be employed than those who had moved within the inner city. All of these differences were statistically significant at the 908 level of confidence. These findings suggest that voucher programs can have a positive effect on the life chances of children if they enable families to find housing in better neighborhoods. On the other hand, they suggest that the disamenities associated with large public housing projects may have significant negative effects. HUD is currently planning several housing experiments that will be based on the Gautreaux model.24 An experimental evaluation that took care to minimize attrition could shed great light on the possible beneficial effects of housing vouchers.

b: In-Kind Programs that Target Specific Services to Children

i) Medicaid

24 Personal commication with Susan Mayer, Department of Sociology, Northwestern University. 
The introduction of Medicaid in 1966 coincided with decreases in infant mortality, increases in hospitalization rates for poor children, and an increase in the frequency of doctor visits for poor relative to non-poor children (Danzinger and stern, 1990; Starfield, 1985). The timing of the decrease in infant mortality is suggestive but not completely compelling evidence of a beneficial effect of Medicaid on the health of poor children because infant mortality periodically falls sharply in response to technological change." Time-series evidence regarding the number of doctor visits is also difficult to interpret since visits for iliness reflect both morbidity and utilization of care. This section reviews recent evidence that Medicaid coverage improves access to preventive care and that these gains are related to declines in the prevalence of low birthweight and infant mortality.

Currie and Thomas (1993a) use the 1986 and 1988 waves of the National Longitudinal Survey's Child Mother file (NLSCM) to examine the relationship between insurance coverage and whether a child had a routine checkup in the last 6 months. As discussed above, visits for preventive care are a more satisfactory measure of utilization than the total number of doctor visits since they do not depend on illness. In each year, mothers were asked whether their child's health. care was covered by either Medicaid or by private insurance. The ability to distinguish between Medicaid and private insurance is useful because children with private health insurance coverage tend to be better off in observable (and presumably also in unobservablel dimensions than children with Medicaid coverage. Hence, if Medicaid has a stronger effect on the utilization of preventive care than private health insurance coverage, then this is strong evidence that the estimated effect reflects insurance coverage rather than omitted characteristics correlated with selection into the Medicaid programs.

ordinary Least Squares estimates of the probability that a child had a routine checkup are shown in Table 5. These regressions include dumm variables for both Medicaid coverage and private health insurance coverage. The excluded

25 For example, up to half of the decline in infant mortality between 1989 and 1990 may be due to the introduction of surfactant therapy - a treatment for premature infants suffering Repiratory Distress Syndrome (Horbar, 1993). 
category is no insurance. The models also include a full set of interactions with an indicator equal to one if the child is African-American. This specification is equivalent to estimating separate models for whites and AfricanAmericans, but allows a ready comparison of the effects of insurance coverage on the two groups. The complete set of control variables is listed in the table notes.

Medicaid coverage is estimated to increase the probability of a routine checkup among white children 3 to 5 years of age by 138 . In contrast, AfricanAmerican children on Medicaid are between $8 \%$ and 158 more likely to receive a checkup at all ages. On the other hand, there are no statistically significant differences between children with private health insurance coverage and those without health insurance coverage, except among white children of school age. This result may reflect the fact that many private insurance policies do not cover preventive pediatric care (Mitchell and Schuman, 1984), so that children may not receive regular preventive care until they enter the school system.

These oLS models do not control for selection into the program. It is possible to do better using these data, because in many cases, there are repeated measures of the same child. Currie and Thomas (1993a) also estimate conditional logit models that include fixed effects for each child. These models control for any unobserved characteristics of the child (such as the education of the mother or innate sickliness) that may be correlated with program participation, and examine the effects of changes in Medicaid and private insurance status on changes in the probability of receiving a checkup. The estimates are remarkably similar to the oLs estimates discussed above.

Another way to control for selection into the Medicaid program is to identify the effects of Medicaid using state-level variation in the coverage of pregnant women and children. As discussed in part 1, the Federal government began expanding the Medicaid coverage of pregnant women and children beginning in 1984. By January 1992, a uniform, minimum floor for coverage had been established that was 2 to 3 times higher than the floor that had existed in the average state only 4 years earlier. However, this floor was raised at very 
different rates in different states.

Currie and Gruber (1993) use data from The National Longitudinal Survey of Youth, Vital Statistics, and the Current Population Survey (CPS) to examine the impact of the Medicaid expansions on the usage of prenatal care, the incidence of low birthweight, and infant mortality. Using CPS data, they first construct two measures of the generosity of state Medicaid programs in each year. The first is the fraction of women aged 15 to 44 who would have been eligible for Medicaid had they become pregnant. The second controls for non-programmatic sources of heterogeneity between states by drawing a random sample of U.S. woman in each year and calculating the fraction that would have been eligible under each state's rules. Using this second measure they find evidence that a 208 increase in the fraction of women eligible for Medicaid would be associated with a 48 decrease in the probability that the initiation of prenatal care was delayed beyond the first trimester. Turning to state-level data from Vital statistics, they also find that the Medicaid expansions were associated with improvements in birth outcomes: A 208 increase in eligibility decreased the incidence of low birthweight and infant mortality by 28 and 78 respectively.

one caveat to these positive results is that early expansions of Medicaid coverage to poor women who had been ineligible for AFDC for reasons of family structure (e.g. single pregnant women without eligible children) had much greater effects on the incidence of low birthweight than later extensions of coverage to women with incomes between 1008 and 1858 of the poverty line. Their analysis of self-reported Medicaid coverage in the CPS suggests that many women in the latter group did not take-up their new benefits. On the other hand, both types of expansions decreased infant mortality rates. Currie and Gruber use data on Medicaid expenditures to infer that at least some of the decline in mortality associated with the later expansions was due to increased utilization of hightech hospital services during and after birth rather than increased utilization of preventive care.

ii) WIC

WIC is more interventionist than traditional welfare programs: Eligibility 
is often determined by medical examinations and blood tests, and nutritional counseling is required. In addition, the types and even brands of foods that can be purchased using WIC coupons are strictly controlled. Many studies find that WIC has positive effects on the utilization of prenatal care and on measures of infant health including birthweight, the incidence of low birthweight, gestational age, and infant mortality. ${ }^{26}$

Schramm (1985) and Devaney et al. (1990) examine the effects of WIC on the Medicaid costs of newborns. The results are of particular interest because they can be used to compare the costs and benefits of the WIC program. Schramm found that in 1980 a dollar spent on WIC reduced Medicaid costs in Missouri by approximately $\$ .80$ in the first 30 to 45 days after birth. Devaney et al. examine Medicaid costs in the first 60 days after birth. Their study examined all Medicaid births in 1987 for Florida, Minnesota, North Carolina, and South Carolina, as well as births from January through June 1988 in Texas. The authors examine women covered by Medicaid, comparing those who were enrolled in WIC to those who were not. Limiting the study to Medicaid eligibles is likely to eliminate some but not all of the observed and unobserved differences between WIC participants and non-participants. The average costs for newborns and their mothers in the 60 days after birth ranged from $\$ 2433$. to $\$ 3822$. depending on the state. The reductions in Medicaid costs for newborns and their mothers that were associated with wIC participation ranged from $\$ 277$. to $\$ 598$. As Table 6 shows, the reductions in Medicaid costs more than offset the costs of providing WIC to these women.

Unfortunately, only two WIC studies, by Metcoff et al. (1985) and Caan et al. (1987), have used random assignment to generate a comparison group. studies that do not use random assignment suffer from the fact that participants may differ from non-participants in unobserved ways. If WIC participants are worse off than non-participants because places are scarce and only the neediest are admitted into the program, then studies that compare WIC participants and nonparticipants will under-estimate the effects of the program. Conversely, if WIC

26 See Devaney, Bilheimer and Schore (1991) for a review. 
participants are more highly motivated or better informed than non-participants, then studies of this type may over-estimate the program's effects.

Without knowing more about the selection mechanism underlying participation it is difficult to assess the probable direction of this bias. However, given that the program is locally administered, the factors governing selection into the WIC program are likely to differ considerably over time and across sites. These factors might include the probability of a doctor referral, the extert to which WIC places are rationed, the amount of advertising, the location of WIC providers, and so on. Hence, the fact that the estimated effects are remarkably constant across samples drawn from different states at different times suggests that the positive results are not entirely driven by the selection of women who are likely to have good outcomes into the program.

Although studies of the effects of WIC on the nutrient intakes of children generally find positive effects of WIC participation (c.f. Fraker (1990)), these studies are also plagued by possible selection bias. One way to control for selection effects is to follow the same child over time. The Centers for Disease control (1978) report the results of a study that followed child wIC participants in 6 states over a two year interval. The study found that after 3 WIC visits the percent of children who were anemic fell from 238 to 108 among children 5 to 23 months of age, and from 248 to 128 among children 24 to 59 months old. In addition, 218 of 6 to 23 month old children entering the program were below the tenth percentile of length-for-age -- after three WIC visits, only $15 \%$ of these children were below this cutoff.

Hicks et al. (1982) report encouraging results from a small-scale study of the effects of WIC participation on later cognitive development. They note that previous studies have established a link between severe malnutrition, protein deficiencies, or anemia, and cognitive deficits. The question is to what extent the less severe malnutrition or anemia that might be present in a U.S. population of poor children presents a threat to child development? Their study focuses on 21 pairs of siblings from rural Louisiana. Because of the design of the WIC program in that state, the younger child in each pair was eligible for 
supplementation beginning in the third trimester of pregnancy, while the older child became eligible for WIC only after the first year. The results show that the "early supplementation" group had significantly higher scores on tests of verbal ability and IQ, and on a "Draw-A-Person" test.

It is possible that these results are biased by the fact that it was always the younger child that received the early supplementation. However, when the authors use measures that were taken when the two children were the same age, such as their grade point averages in grade one and their heights-for-age, they still find that early supplementation has a significant effect. They note that in general there is a slight negative association between parity and IQ, so the finding that the younger children had higher IQ's is unlikely to be solely an artifact of birth order.

\section{iii) School Nutrition Programs}

In 1979 a bi-partisan senate committee requested the secretary of Agriculture to commission a study of school nutrition programs. This request resulted in the National Evaluation of School Nutrition Programs (NESNP), which surveyed students, parents, and school food service administrators.

Hanes et al. (1984) use the NESNP to compare the nutritional content of the breakfasts and Iunches of participants and non-participants. They also examine nutrient intakes over a 24 hour period in order to assess the extent to which families compensate for school meals by reducing the child's home food consumption. They find that school lunches contain more of almost all the nutrients that were examined than non-participant lunches. School lunch participants also have higher 24 hour nutrient intakes, which indicates that families do not entirely offset the effects of food supplementation.

The effects of the School Breakfast program are less striking. School breakfasts contain more calcium, phosphorus, protein, and magnesium than other breakfasts. But they have less vitamin $A, B_{6}$, Niacin, thiamin and iron. Children who have a school breakfast have higher 24 hour intakes of calcium and phosphorus than those who have another breakfast, which indicates that the initial gains in intakes of other nutrient are of set over the course of the day. 
However, the availability of a school breakfast does have a positive effect on the probability that a child eats breakfast, and children who eat breakfast have higher 24 hour nutrient intakes than children who do not.

The differences in the effects of the NSLP and the SBP on nutrient intakes probably reflect differences in Federal standards. Lunches must conform to Federally determined "meal patterns" that specify the types, amounts, and methods of preparation of food. The standards for breakfasts are much looser, perhaps because the government wishes to encourage school districts to participate. The two nutrients that are consumed in greater quantities over a 24 hour period by school breakfast participants are both found in milk, which is a compulsory component of the breakfast meal pattern (Radkowski and Gale, 1984b). Hence, it seems that the effectiveness of the school nutrition programs is directly related to the strictness of the federal guidelines governing them.

Surprisingly, there have been few attempts to evaluate the effects of school nutrition programs on cognitive outcomes. In one of the more compelling studies, Meyers et al. (1988) examined 1092 third to sixth grade children in Lawrence, Massachusetts before and after the SBP was introduced in their school in 1987. They found that the Breakfast Program participants showed greater improvements on the Comprehensive Test of Basic Skills, relative to their initial scores, than non-participant children. SBP participation also reduced tardiness. iv) Head Start

Mckey et al. (1985) provide one of the most recent surveys of the Head Start literature. Much of the research focuses on assessing cognitive gains. The consensus of 72 experimental studies is that Head start has positive effects on IQ and measures of "school readiness" that fade out by the end of the third grade. However, as discussed above, experimental evaluations of long-term outcomes may be severely biased by attrition from the sample. Also, most studies do not provide separate analyses by race, although racial differences in the levels of scores on standardized tests suggest that the effects of head start may differ by race.

Currie and Thomas (1993b) use data from 1986, 1988, and 1990 waves of the 
NLSCM to investigate the longer-term cognitive effects of Head Start. They provide one of the first analyses of the Head start program based on a large national sample of children who attended regular Head start programs. About \&\$, of white children, 168 of Hispanic childzen and 278 of African-American chilaren in their sample participated. They find some evidence of longer-term cognitive gains to participation in Head Start: Head start appears to have a positive effects on the peabody picture Vocabulary Test (PPVT) scores of white and Hispanic children over 8 years old. However, there are no effects on the PPVT scores of African-American children or on the mathematics or reading scores of any children in this age group.

Estimates based on differences between siblings are shown in Table 7 . These models control for unobserved characteristics common to both children by including a fixed effect for each family. These models also include an indicator variable equal to one if a child attended another type of preschool. Currie and Thomas find that even within the same family, children tend to attend preschool when the family is relatively well off. In contrast, they attend head start when the family is relatively disadvantaged. Hence, the fact that head start has a greater impact on test scores than preschool attendance suggests that the estimated effect is unlikely to be an artifact of patterns of selection into the two types of programs.

Currie and Thomas also find that past participation in Head start reduces the probability that white and Hispanic children 10 years and older reported repeating a grade. Estimates from models with family fixed effects are shown in Table 8. Attendance at a non-head start preschool has no effect on the probability of grade repetition. These results are consistent with those of Copple, Cline, and Smith (1987) who followed children in 33 Philadelphia schoois from school entry up to grade 6 and found that children who had participated in Head Start were 3 to 128 less likely to have repeated a grade (depending on the sample). They were also less likely to have been placed in remedial education. in addition, head start children had 2 to $23 \%$ fewer absences and were more likely to be present when standardized tests were administered. It would be useful t $=0$ 
replicate these results in other data sets since 708 of the students in Copple, Cline and Smith's initial sample had been lost by the time they reached the sixth grade, and their estimates may be subject to severe attrition bias.

In addition to improving cognitive attainment, Head start aims to "provide a comprehensive health services program which includes a broad range of medical services.." (Head start Bureau, 1992). Thirty-four studies reviewed by Mckey et al. provide qualitative evidence that children in Head start are more likely than non-participants to receive routine checkups, dental care, and screenings for speech, language, developmental delays, vision, and hearing.

Currie and Thomas (1993b) provide quantitative analyses of the effects of Head start participation on the probability of having been immunized against measles as of 1990 and on height-for-age. In addition to mandating the provision of preventive medical care, the Head start program performance standards state that "every child in a part-day program will receive a quantity of food in meals... and snacks which provides at least $1 / 3$ of daily nutritional needs..." (Head start Bureau, 1992). Both nutritious food and better medical care are expected to improve child growth. Hence, there is some reason to expect a positive effect of participation in Head start on child height as well as on immunization rates.

Figure 4 shows non-parametric estimates of the relationship between Head start and preschool status, permanent income", and immunization status in 1990 . The figure shows that for white and African-American children, the probability of having been immunized against measles is significantly higher at all income levels for children who were in Head start relative to those who went to other

27 Currie and Thomas (1993b) define permanent income as the logarithm of average annual household income between 1978 and 1990 (in real 1990 dollars). Use of this measure should attenuate the influence of measurement error and breaks the link between household income at a point in time and eligibility for the Head start program. Household permanent income is about $\$ 29,000$ for the average white child, $\$ 23,000$ for Hispanics and $\$ 18,000$ for African-Americans in this sample. 
preschools. ${ }^{20}$ The latter are, in turn, more likely to have been immunized than those who did not attend any preschool. Among Hispanics, both children who went to Head Start and those who went to other preschools are more likely to have been immunized then those who did not attend any preschool. ${ }^{29}$ Although they do not have data about the utilization of other preventive care services, Currie and Thomas suggest that if Head start children are more likely to receive immunizations, they may be also be more likely to receive the other services mandated by the program. Finally, they show that, conditional on household permanent income, children who attended Head start are significantly taller than those who attended no preschool. These benefits of Head start persist when family fixed effects are controlled for: Head start participation is associated with increases in the probabilities that white and African-American children receive measles shots of 108 and $12 \%$ respectively, and African-American children who attended Head start are significantly taller than their siblings who did not. 30

\section{Conclualons}

The current state of knowledge about the effects of welfare programs on child well-being is sumarized in Table 9. The table presents a matrix of programs and outcomes: Each cell shows what we know about the effects of a particular program on a given outcome. For brevity's sake, only positive findings have been reported in the table. The most striking feature of Table 9

20 Figures 2 and 3 show locally-weighted smoothed scatterplots (LOWESS) (Cleveland, 1979) which are a nearest neighbor-type estimator. Essentially, each observation is replaced by its predicted value based on a weighted regression using the observations in a band around it. Hence the shape of the estimated function is determined locally throughout the distribution of income (See, also, Hardle, 1990).

29 All these differences are statistically significant at the 958 level of confidence.

30 These fixed effects estimates may be biased downwards if there is measurement error, or if there are positive spill-over effects from one child to another. 
is that there are many empty cells -- we clearly need to learn a great deal more about how these programs work before we can make informed public poiicy.

However, the cells with entries do tell a consistent story: Programs that target services directly to children have the largest measured effects, while unrestricted cash transfer programs have the smallest. Perhaps unsurprisingly, families seem to treat cash transfers the same way that they treat other cash income -- expenditures on goods that directly increase the well-being of children may increase, but so do expenditures on other goods. As a result, large cash transfers under the NIT program had only small and inconsistent effects on the nutrition and schooling attainment of poor children.

Programs that provides transfers to parents that are earmarked for specific purposes also appear to have uncertain effects. There is little evidence that participation in the Food stamp Program increases the nutrient intake of poor children, although it has not been proven that it does not. The evidence on housing programs is mixed: On the one hand, the physical condition of public housing may be superior to that of alternative housing, and the cash value of the transfer may be very large relative to the size of the family's income. On the other hand, the disamenties associated with large public housing complexes are notorious. The Gautreaux experiment suggests that voucher programs that enable families to move to better neighborhoods may have large positive impacts on schooling attainment and employment probabilities. But difficulties in accessing Section 8 housing probably prevent many families from realizing potential benefits. Finally, Medicaid, WIC, the School Lunch Program, and Head start all have demonstrable positive effects on poor children.

One glaring omission from the current study is that there has been no discussion of multiple program participation. Many children are covered by more than one program. For example, AFDC participants are covered by Medicaid and are automatically eligible for Food stamps. As of 1990, half of AFDC children received free school lunches, 358 lived in public or subsidized rental housing, and 198 participated in WIC. Conversely, half of all Food stamp recipients, 428 of Medicaid recipients, $38 \%$ of WIC recipients, and $24 \%$ of those in public housing 
also received AFDC. Moffitt (1992) estimates that in 1984, 26.48 of nonelderly single-parent families received AFDC, Medicaid, and Food Stamps, and 118 received at least one benefit in addition to AFDC. It is impossible to say how multiple program participation affects the child outcomes discussed above since there has been virtually no research on this topic.

At this point it is instructive to consider the costs as well as the benefits of two policy options. It is unlikely that AFDC benefit levels will be raised in the near future given the unpopularity of the program. However, there has been discussion of raising the EITC to "guarantee a working wage so that no American who works full-time is forced to raise children in poverty" (Clinton and Gore, 1992). In 1992, a family of four with one earner working full time at $\$ 5.00$ per hour (approximately the minimum wage) would have required a credit of $\$ 4000$. to bring them up to the poverty line. In fact, such a family received a credit of approximately $\$ 1400$. A very crude calculation is that increasing the generosity of the program three times would raise the cost from the current 7 billion to 21 billion dollars. And this increase would only benefit children of working parents.

A second policy that has been much discussed, is extending the benefits provided by targeted programs to all poor children. In the absence of additional reforms, the Medicaid expansions that have already been implemented will cover all poor children by the turn of the century. If there are approximately 12 million poor children and 288 of them are uninsured ${ }^{31}$, and if the average cost of covering these children is equal to the current cost of covering an AFDC child, then the cost of the Medicaid expansions will be about $\$ 2.3$ billion. The costs of expanding WIC and Head start to all eligible children would be $\$ 1.5$ and $\$ 4.5$ billion respectively. Finally, it would cost $\$ .8$ billion to restore the cuts that have been made in the School Lunch Program. Hence, if a choice had to be made, these calculations suggest that the more cost effective policy would be to increase expenditures on targeted programs.

3. In 1988, 178 of all children and 288 of children with family incomes less than $\$ 10,000$ were without health insurance coverage of any kind (Bloom, 1990 ). 
Tab10 1: Tronds in Program Expenditures (b11110n: $1990 \$)^{1}$

\begin{tabular}{|c|c|c|c|}
\hline Program & 1975 & 1980 & 1990 \\
\hline $\begin{aligned} \text { Cash } & \text { Trandiers } \\
A F D C & (\text { total) } \\
& (\text { federal only) }\end{aligned}$ & $\begin{array}{l}20.4 \\
11.2\end{array}$ & $\begin{array}{l}19.0 \\
10.2\end{array}$ & $\begin{array}{l}18.5 \\
10.1\end{array}$ \\
\hline $\begin{array}{l}\text { Earned Income Tax Credit (total) } \\
\text { (refunded portion of credit) }\end{array}$ & $\begin{array}{l}3.2 \\
2.2\end{array}$ & $\begin{array}{l}3.2 \\
2.2\end{array}$ & $\begin{array}{l}6 \cdot 9 \\
5 \cdot 3\end{array}$ \\
\hline $\begin{array}{l}\text { Earmarked Trangter: } \\
\text { Food stamps }\end{array}$ & $10.2^{2}$ & 13.8 & 15.1 \\
\hline Housing Assistance & $6.3^{4}$ & 8.6 & 10.6 \\
\hline $\begin{aligned} \text { Targeted } & \text { Transters } \\
\text { Medicaid } & \text { (total) } \\
& \text { (federal only) } \\
& \text { (to dependent children) } \\
& \text { (to adults in families } \\
& \text { with dependent children) }\end{aligned}$ & $\begin{array}{r}30.6 \\
17.2 \\
5.4 \\
5.1\end{array}$ & $\begin{array}{r}40.9 \\
23.2^{3} \\
5.1^{3} \\
5.5^{3}\end{array}$ & $\begin{array}{r}72.5 \\
41.1 \\
9.1 \\
8.6\end{array}$ \\
\hline WIC & $.6^{4}$ & .7 & 2.1 \\
\hline School Lunch & $4.5^{4}$ & 4.8 & 3.7 \\
\hline Head Start & 1.0 & 1.1 & 1.6 \\
\hline
\end{tabular}

Notes:

: These figures were taken from U.S. House of Representatives (1992), pages 654, 1019, 1616, 1651, 1680,1684 , and 1689,1695 .

The figure for 1975 includes adninistrative costs. The figures for 1980 and 1990 do not.

These figures are for 1981 .

- These figures are for 1977 . 
Table 2, Caseloade for 8 Large Federal programe (mtllfons)

\begin{tabular}{|c|c|c|c|}
\hline Program & 1975 & 1980 & 1990 \\
\hline $\begin{array}{ll}\text { Canh } & \text { Trangiere } \\
\text { AFDC } & \text { (total recipients) } \\
& \text { (child recipients) }\end{array}$ & $\begin{array}{r}11.1 \\
8.0\end{array}$ & $\begin{array}{r}10.6 \\
7.3\end{array}$ & $\begin{array}{r}11.2 \\
7.6\end{array}$ \\
\hline $\begin{array}{l}\text { Earned Income Tax credit } \\
\text { (* families) }\end{array}$ & 6.2 & 7.0 & 13.3 \\
\hline$\frac{\text { Earmarked Transfere }}{\text { Food stamps (total recipients) }}$ & 16.3 & 19.2 & 20.0 \\
\hline Housing Assistance (* households) & $3.2^{1}$ & 4.0 & 5.4 \\
\hline $\begin{aligned} \text { Targeted Transfers } \\
\text { Medicaid (total recipients) } \\
\text { (child recipients) }\end{aligned}$ & $\begin{array}{r}22.0 \\
9.6\end{array}$ & $\begin{array}{r}21.6 \\
9.3\end{array}$ & $\begin{array}{l}25.3 \\
11.2\end{array}$ \\
\hline $\begin{aligned} \text { WIC } & \text { ( } \text { * women) } \\
& \text { (* infants) } \\
& \text { (* children) }\end{aligned}$ & $\begin{array}{l}.2^{1} \\
.2 \\
.5\end{array}$ & $\begin{array}{r}.4 \\
.5 \\
1.0\end{array}$ & $\begin{array}{l}1.0 \\
1.4 \\
2.1\end{array}$ \\
\hline $\begin{aligned} \text { School Lunch (* any meals) } & \text { (* with free mea1s) }\end{aligned}$ & $\begin{array}{l}26.3^{1} \\
10.5\end{array}$ & $\begin{array}{l}26.6 \\
10.0\end{array}$ & $\begin{array}{l}12.8 \\
10.3\end{array}$ \\
\hline Head Start & .4 & .4 & .6 \\
\hline
\end{tabular}




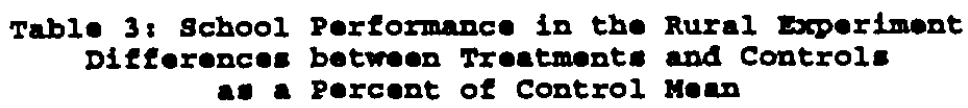

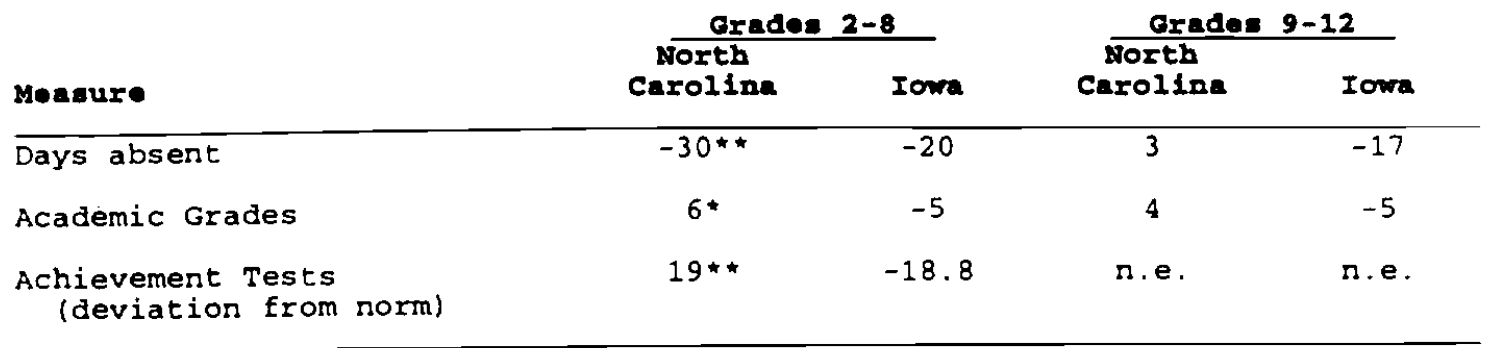

Source: Maynard and Crawford (1976). There were 847 children.

* Significant at the 908 level of confidence.

* * Significant at the 958 level of confidence.

n.e. Not estimated due to lack of data.

Table 4

Household Nutrient Avallability as a Percentage of the RDA for Persons Eating in the Households

\begin{tabular}{|c|c|c|c|}
\hline Nutrient & $\begin{array}{c}\text { FSP Participants } \\
\text { (a) }\end{array}$ & $\begin{array}{c}\text { FSP Nonparticipants } \\
\text { (b) }\end{array}$ & $\begin{array}{c}\text { Difference } \\
(a-b)\end{array}$ \\
\hline Food Energy & 1398 & 1218 & +188 \\
\hline Protein & 232 & 203 & +29 \\
\hline Calcium & 119 & 111 & +8 \\
\hline Iron & 151 & 137 & +14 \\
\hline Magnesium & 134 & 123 & +11 \\
\hline Phosphorous & 202 & 183 & +19 \\
\hline Vitamin A & 213 & 178 & +35 \\
\hline Thiamin & 194 & 165 & +29 \\
\hline Riboflavin & 204 & 180 & +24 \\
\hline Vitamin B6 & 132 & 114 & +18 \\
\hline Vitamin $\mathrm{B} 12$ & 235 & 191 & +44 \\
\hline Vitamin C & 290 & 264 & +26 \\
\hline
\end{tabular}


Table 5: Ors Estimates of the Effects of Medicald and Private Health Insurance on the Probabllity of a Routine Checkup

\begin{tabular}{|c|c|c|c|}
\hline Child Age in 88: & $\begin{array}{r}(1) \\
1-3 \\
\end{array}$ & $\begin{array}{r}\langle 2\rangle \\
3-5 \\
\end{array}$ & $\begin{array}{r}(3) \\
5-9 \\
\end{array}$ \\
\hline Intercept & $\begin{array}{l}.226 \\
(.237)\end{array}$ & $\begin{array}{l}.712 \\
(.290)\end{array}$ & $\begin{array}{l}.104 \\
(.290)\end{array}$ \\
\hline African-American & $\begin{array}{l}.238 \\
(.387)\end{array}$ & $\begin{array}{l}-.027 \\
(.482)\end{array}$ & $\begin{array}{l}-.406 \\
(.447)\end{array}$ \\
\hline \multicolumn{4}{|l|}{ Type of Insurance } \\
\hline Medicaid & $\begin{array}{l}.044 \\
(.036)\end{array}$ & $\begin{array}{l}.133 \\
(.039)\end{array}$ & $\begin{array}{l}.043 \\
(.037)\end{array}$ \\
\hline $\begin{array}{l}\text { African-American } \\
\quad \text { Medicaid }\end{array}$ & $\begin{array}{l}.051 \\
(.061)\end{array}$ & $\begin{array}{l}-.052 \\
(.069)\end{array}$ & $\begin{array}{l}.102 \\
(.060)\end{array}$ \\
\hline Private Ins. & $\begin{array}{l}.031 \\
(.028)\end{array}$ & $\begin{array}{l}.005 \\
(.033)\end{array}$ & $\begin{array}{l}.069 \\
(.032)\end{array}$ \\
\hline $\begin{array}{l}\text { African-American } \\
\text { * Private Ins. }\end{array}$ & $\begin{array}{l}-.008 \\
(.054)\end{array}$ & $\begin{array}{l}-.044 \\
(.063)\end{array}$ & $\begin{array}{l}-.046 \\
(.056)\end{array}$ \\
\hline \multicolumn{4}{|c|}{ Maternal Characteristics } \\
\hline Permanent Income & $\begin{array}{l}-.004 \\
(.023)\end{array}$ & $\begin{array}{l}-.057 \\
(.027)\end{array}$ & $\begin{array}{l}-.040 \\
(.027)\end{array}$ \\
\hline $\begin{array}{l}\text { African-American } \\
\star \text { Income }\end{array}$ & $\begin{array}{l}.034 \\
(.039)\end{array}$ & $\begin{array}{l}.005 \\
(.048)\end{array}$ & $\begin{array}{l}.041 \\
(.044)\end{array}$ \\
\hline Top Grade in 88 & $\begin{array}{l}.021 \\
(.006)\end{array}$ & $\begin{array}{l}.019 \\
(.008)\end{array}$ & $\begin{array}{l}.017 \\
(.008)\end{array}$ \\
\hline $\begin{array}{l}\text { African-American } \\
\text { * Top Grade }\end{array}$ & $\begin{array}{l}-.014 \\
(.014)\end{array}$ & $\begin{array}{l}-.004 \\
(.017)\end{array}$ & $\begin{array}{l}.019 \\
(.015)\end{array}$ \\
\hline $\begin{array}{l}\text { R-Squared } \\
\text { \# Observations }\end{array}$ & $\begin{array}{l}.035 \\
2183\end{array}$ & $\begin{array}{l}.044 \\
2260\end{array}$ & $\begin{array}{l}.033 \\
2642\end{array}$ \\
\hline
\end{tabular}

Notes: Standard errors in parentheses. All regressions also included: The mother's AFQT score; an indicator equal to 1 if she was in the poverty sample; an indicator equal to 1 if the mother lived in an urban area at age 14; the child's gender; county income per capita; the number of physicians per 1000 state residents; the number of hospital beds per 1000 state residents; the state infant mortality rates; dummy variables for residence in the northeast, south, or west; an indicator equal to one if the data came from the 1986 survey and zero otherwise; and interactions of all these variables with the indicator for African-Americans. Since observations from both the 1986 and 1988 NLSCM surveys have been pooled, a control for the earlier survey was included to allow for possible differences between the two waves.

Source: Currie and Thomas (1993a). 
Tablo 6: Estimated Benefit-Cost Ratios for WIC Participants

\begin{tabular}{|c|c|c|c|}
\hline & $\begin{array}{l}\text { Estimated } \\
\text { Savings in } \\
\text { Medicaid } \\
\text { Costs }\end{array}$ & $\begin{array}{l}\text { Estimated } \\
\text { Prenatal wIC } \\
\text { Costs per } \\
\text { Participant }\end{array}$ & $\begin{array}{c}\text { Estimated } \\
\text { Benefit } \\
\text { Cost Ratios }\end{array}$ \\
\hline \multicolumn{4}{|l|}{ Florida } \\
\hline Newborns and Mothers & $\$ 347$ & $\$ 196$ & 1.77 \\
\hline \multicolumn{4}{|l|}{ Minnesota } \\
\hline Newborns and Mothers & $\$ 277$ & $\$ 151$ & 1.83 \\
\hline \multicolumn{4}{|l|}{ North Carolina } \\
\hline $\begin{array}{l}\text { Newborns } \\
\text { Newborns and Mothers }\end{array}$ & $\begin{array}{l}\$ 744 \\
\$ 598\end{array}$ & $\begin{array}{l}\$ 191 \\
\$ 191\end{array}$ & $\begin{array}{l}3.90 \\
3.13\end{array}$ \\
\hline \multicolumn{4}{|l|}{ South Carolina ${ }^{c}$} \\
\hline Newborns and Mothers & $\$ 565$ & $\$ 232$ & 2.44 \\
\hline \multicolumn{4}{|l|}{ Texas } \\
\hline $\begin{array}{l}\text { Newborns } \\
\text { Newborns and Mothers }\end{array}$ & $\begin{array}{l}\$ 573 \\
\$ 493\end{array}$ & $\begin{array}{l}\$ 202 \\
\$ 202\end{array}$ & $\begin{array}{l}2.84 \\
2.44\end{array}$ \\
\hline
\end{tabular}

Notes:

"Medicaid costs are from birth to 60 days after birth.

All estimates are statistically significant at the 01 level (two-tail test), except in Minnesota, where the estimate is statistically significant at the .07 level (two-tail test) and at the .03 level (one-tail test).

Medicaid costs refer to hospital costs only.

Source: Devaney, Bilheimer, and Schore (1990). 


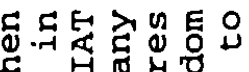

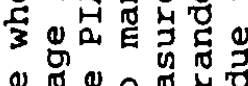

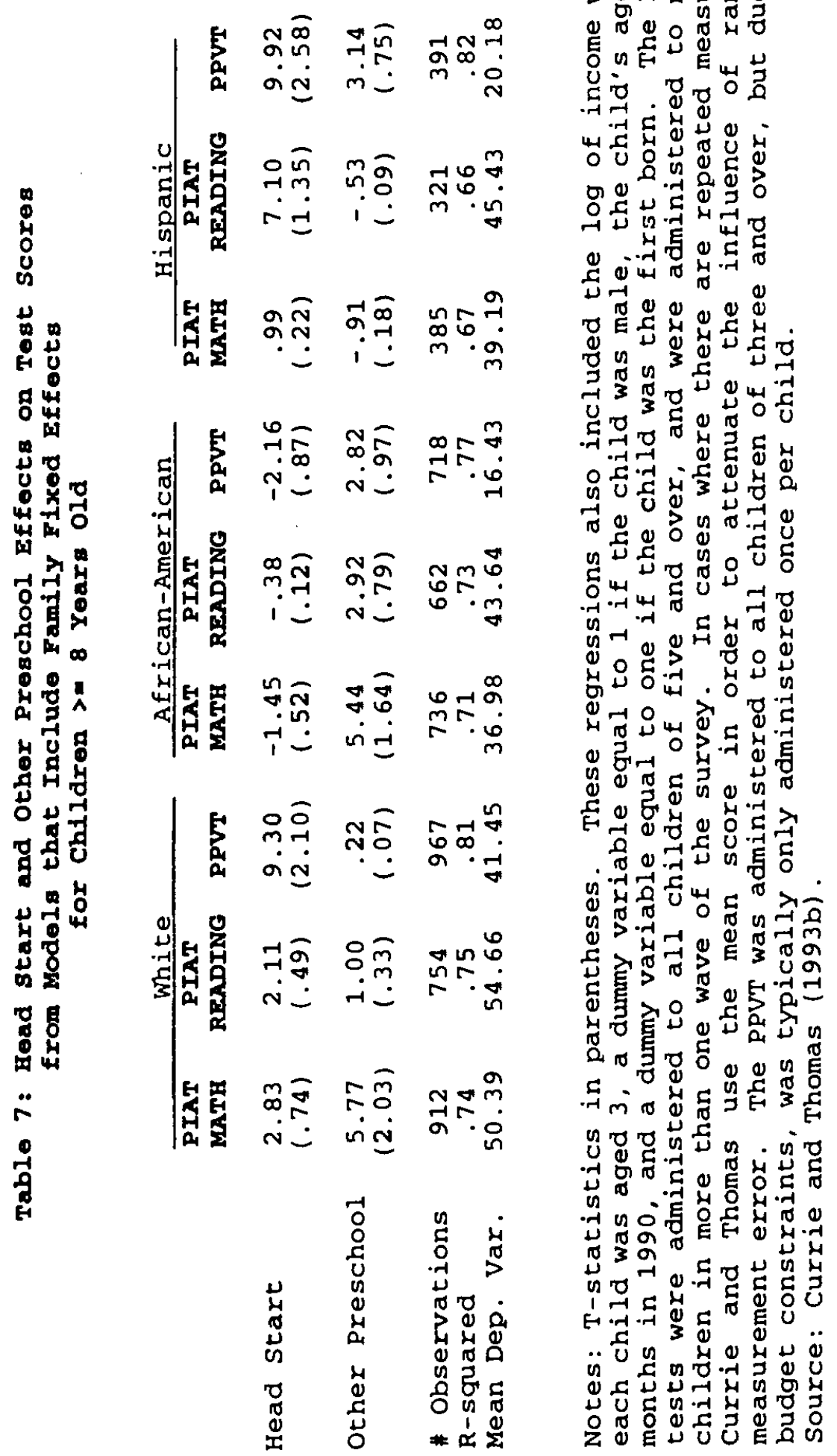




\section{Table 8: Head Start Effects on Grade Repetition, from Models that Include Family Fixed Effects, for Chtldren >= 10 Years old}

\begin{tabular}{|c|c|c|c|}
\hline Head Start & $\frac{\text { White }}{-.51}$ & $\frac{\begin{array}{c}\text { African } \\
\text { American }\end{array}}{(.03}$ & 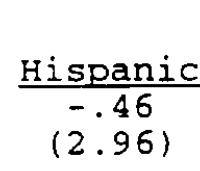 \\
\hline Other Preschool & $\begin{array}{l}-.08 \\
(.67)\end{array}$ & $\begin{array}{l}-.17 \\
(1.34)\end{array}$ & $\begin{array}{l}-.005 \\
(.02)\end{array}$ \\
\hline $\begin{array}{c}\text { Log Income } \\
\text { at Age } 3\end{array}$ & $\begin{array}{l}.08 \\
(.75)\end{array}$ & $\begin{array}{l}-.14 \\
(1.10)\end{array}$ & $\begin{array}{l}-.38 \\
(2.04)\end{array}$ \\
\hline Male & $\begin{array}{l}-.06 \\
(.97)\end{array}$ & $\begin{array}{l}-.13 \\
(1.93)\end{array}$ & $\begin{array}{l}-.01 \\
(.09)\end{array}$ \\
\hline $\begin{array}{l}\text { Age in Months } \\
1990\end{array}$ & $(1.004)$ & $\begin{array}{l}-.001 \\
(.35)\end{array}$ & $(1.01)$ \\
\hline First Born & $\frac{-.13}{(1.35)}$ & $\begin{array}{l}.05 \\
(.57)\end{array}$ & $\begin{array}{l}-.16 \\
(1.20)\end{array}$ \\
\hline $\begin{array}{l}\text { \# Observations } \\
\text { R-squared } \\
\text { Mean Dep. Var. }\end{array}$ & $\begin{array}{l}269 \\
.63 \\
.36\end{array}$ & $\begin{array}{l}311 \\
.59 \\
.47\end{array}$ & $\begin{array}{l}141 \\
.65 \\
.32\end{array}$ \\
\hline
\end{tabular}



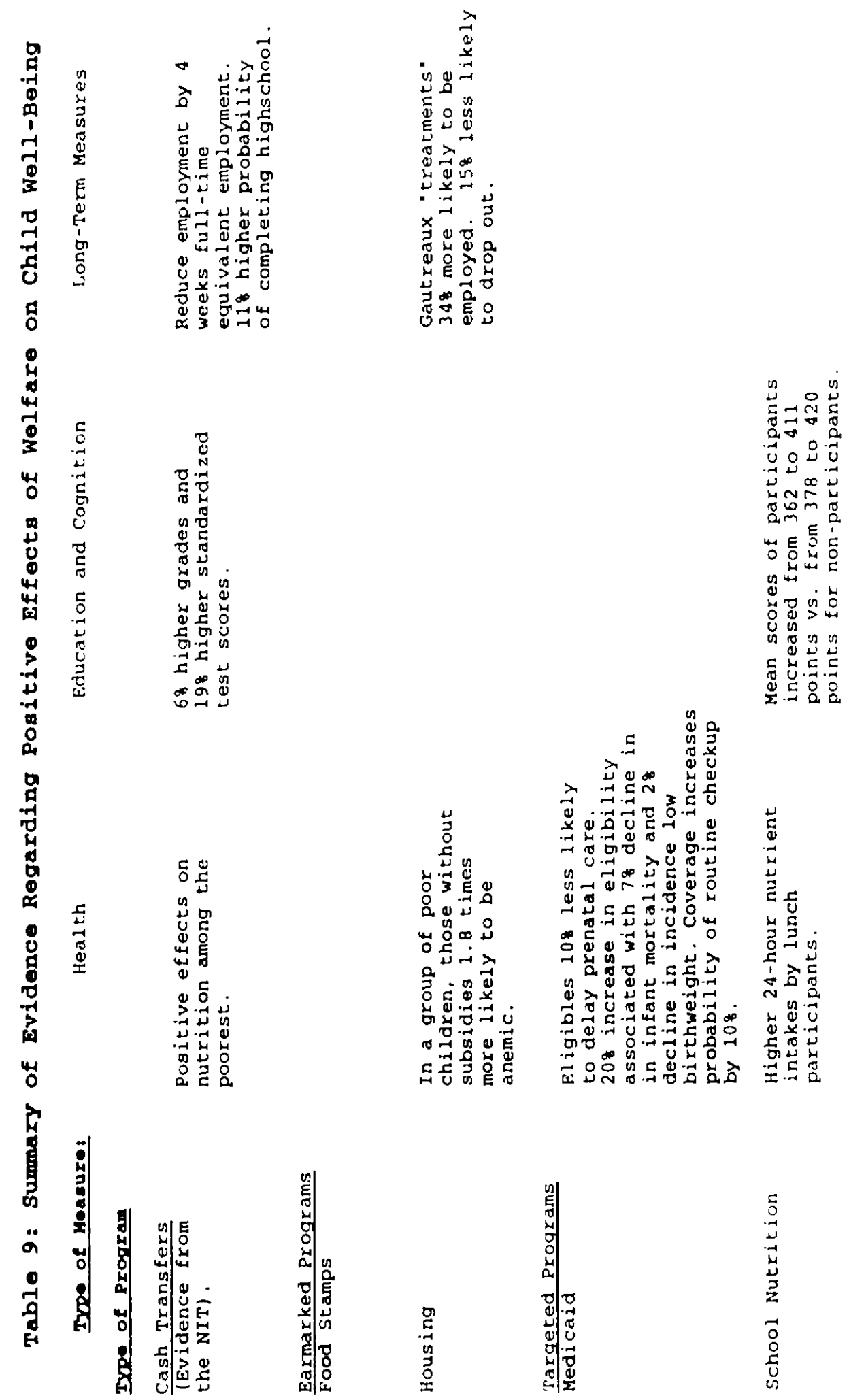

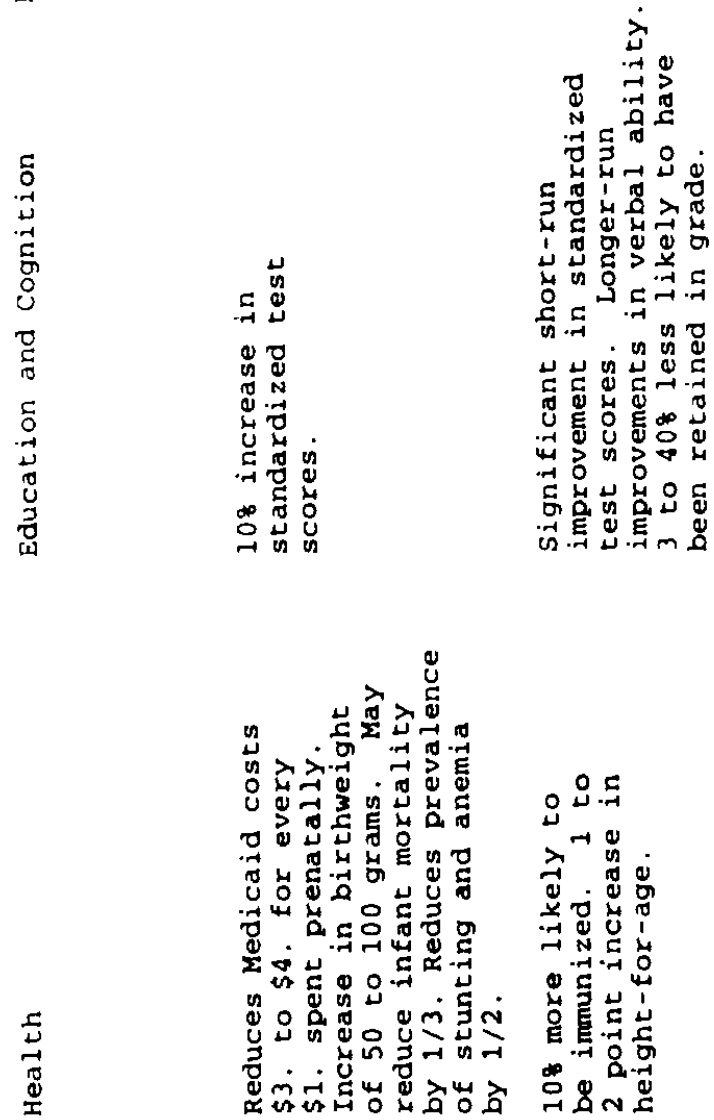

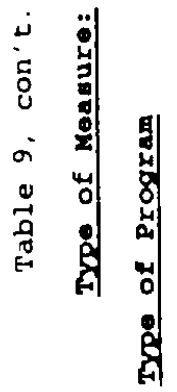

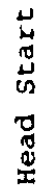




\section{References}

Angrist, Joshua. "Lifetime Earnings and the Vietnam Era Draft Lottery: Evidence from Social Security Administration Records," American Economic Review, June 1990, 1-336.

Apgar, William. "Which Housing Policy is Best," Housing Policy Debate, $1 \# 1,1990,1-32$.

Ashenfelter, Orley and Mark Plant. "Non-Parametric Estimates of the Labor Supply Effects of the NIT," Journal of Labor Economics, $8 \# 1$, January 1990, 396-415.

Becker, Gary. A Treatise on the Family, Cambridge MA: Harvard University Press, 1981.

Blanchard, Lois, et al. Food Stamp SSI/Elderly Cashout Demonstration Evaluation, Washington D.C.: USDA Food and Nutrition Service, 1982.

Blank, Rebecca and Patricia Ruggles. "When do Women use AFDC and Food Stamps? The Dynamics of Eligibility vs. Participation, " NBER Working Paper \#4429, August 1993.

Blau, Francine and Adam Grossberg. "Maternal Labor Supply and Children's Cognitive Development", NBER WP \#3536, Dec. 1990.

Bloom, Barbara. "Health Insurance and Medical Care", Advance Data from Vital and Health Statistics of the National Center for Health Statistics, \#188, Public Health Service, Washington D.C., October 1. 1990 .

Caan, Bette, Donna Horgen, Sheldon Margen et al. "Benefits Associated with WIC Supplemental Feeding During the Interpregnancy Interval," The American Journal of Clinical Nutrition, 45, 1987, 29-41.

Cain, Glen and Douglas Wissoker. "A Reanalysis of Marital Stability in the Seattle-Denver Income-Maintenance Experiment," American Journal of Sociology, 95 (March 1990): 1235-69.

Clarkson, Kenneth. Food Stamps and Nutrition, washington D.C.: American Enterprise Institute, 1975.

Cleveland, W.S. "Robust Locally-Weighted Regressions and Smoothing Scatterplots," Journal of the American Statistical Association, 74. $1979,829-836$.

Clinton, William and Albert Gore. Putting People First, New York: Times Books, 1992.

Commerce Clearing House. Medicare and Medicaid Guide, New York: Commerce Clearing House, 1987. 
Copple, C.E. Cline, M.G, and Smith, A.N. Path to the Future: LongTerm Effects of Head start in the Philadelphia School District, Washington D.C.: Head Start Bureau, U.S. Department of Health and Human Services, 1987.

Currie, Janet and Duncan Thomas. "Medicaid and Medical Care for Children," NBER Working Paper \# 4284, March 1993, revised May 1993a.

Currie, Janet and Duncan Thomas. "Does Head start Make a Difference?," NBER Working Paper \# 4406, July 1993.

Currie, Janet and Nancy Cole. "Welfare and Child Health: The Link Between AFDC Participation and Birth Weight", The American Economic Review, 283 \#3, September 1993.

Currie, Janet and Jonathan Gruber. "Insurance Coverage, Access to Care, and Birth Outcomes: Evidence from Medicaid Expansions," National Bureau of Economic Research, mimeo, October 1993.

Danzinger, Sheldon and Jonathan Stern. "The Causes and Consequences of Child Poverty in the United States". Population Studies Center, University of Michigan, Research Report No. 90-194, September 1990.

Desai, Sonalde; P. L. Chase-Lansdale and Robert Michael. "Mother or Market? Effects of Maternal Employment on the Intellectual Ability of 4-Year-old Children", Demography, 26 \#4, November 1989, 545-561.

Devaney, Barbara, Pamela Haines and Robert Moffitt. Assessing the Dietary Effects of the Food Stamp Program, Volume 2: Empirical Results, Mathematica Policy Research Inc.: Washington D.C., Project $\# 7665-450$ and 7665-710, February 14, 1989.

Devaney, Barbara, Linda Bilheimer, and Jennifer Schore. The Savings in Medicaid Costs for Newborns and Their Mothers from Prenatal Participation in the WIC Program, Mathematica Policy Research, Inc.: Washington D.C., October 1990.

Ellwood, David and Mary Jo Bane. "The Impact of AFDC on Family Structure and Living Arrangements", in Research in Labor Economics, R. Ehrenberg (ed), 7, Greenwich: JAI Press, 1985, 137-207.

Ensminger, Margaret and Anita Slusarcick. "Paths to Highschool Graduation or Dropout: A Longitudinal Study of a lst Grade Cohort," Sociology of Education, 65, April 1992, 95-113.

Fraker, Thomas. The Effects of Food Stamps on Food Consumption: A Review of the Literature, Washington D.C.: USDA Food and Nutrition Service, October 1990a.

Fraker, Thomas. Analyses of the 1985 Continuing survey of Food Intakes by Individuals Volume II -- Estimating the Effects of the WIC and Food stamp programs on Dietary Intake by women and Young 
Children, Washington D.C.: USDA Food and Nutrition Service, March 16 , $1990 \mathrm{~b}$.

Gottschalk, Peter. "AFDC Participation Across Generations", The American Economic Review, 80 \#2, May 1990, 367-371.

Hannan, Michael and Nancy Tuma. "A Reassessment of the Effect of Income Maintenance on Marital Dissolution in the Seattle-Denver Experiment," American Journal of Sociology, 95 \#5, March 1990, 127098 .

Hanes, S., J. Vermeersch, and S. Gale. "The National Evaluation of School Nutrition Programs: Program Impact on Dietary Intake". The American Journal of Clinical Nutrition, 40, August 1984, 390-413.

Hardle, W. Applied Nonparametric Regression, New York: Cambridge University Press, 1990.

Head Start Bureau, Head Start Program Performance Standards, U.S. Department of Health and Human Services Publication * ACF 92-31131. June 1992 .

Hicks, Lou, Rose Langham, and Jean Takenaka. "Cognitive and Health Measures Following Early Nutritional Supplementation: A Sibling Study". American Journal of Public Health, 72, 1982, 1110-1118.

Hi11, Anne and June $O^{\prime N e i l 1 . ~ " T h e ~ T r a n s m i s s i o n ~ o f ~ C o g n i t i v e ~}$ Achievement Across Three Generations", Baruch College City University of New York, mimeo, June 1992.

Horbar, Jeffrey, et al. "Decreasing Mortality Associated with the Introduction of Surfactant Therapy: An Observational Study of Neonates Weighing 601 to 1300 Grams at Birth, " Pediatrics, 82 \#2, August $1993,191-196$.

Institute of Medicine, Preventing Low Birthweight, washington D.C.: National Academy Press, 1985.

Johnson, Gary. "Rent Paying Ability and Racial Settlement Patterns: A Review and Analysis of Recent Housing Allowance Evidence, " American Journal of Economics and Sociology, 45 \#1, January 1986, $17-26$.

Jones, Jean Yavis: "The WIC Program: Eligibility, Coverage, and Funding", Congressional Research Service, January 10, 1992.

Jones, Jean Yavis. "Child Nutrition: Program Information, Funding, and Participation FY 1980-FY 1990", Congressional Research Service, September $10,1990$.

Kehrer, Barbara and Charles Wolin. "Impact of Income Maintenance on Low Birth Weight: Evidence from the Gary Experiment, "The Journal of Human Resources, XIV \#4, 1979, 434-462. 
Kennedy, Stephen and Merly Finkel. Report of First Year Findings for the Freestanding Housing Voucher Demonstration, Cambridge: ABT Associates, Inc. 1987.

Korenman, Sanders and Jane Miller. Food Stamp Program Participation and Maternal and Child Health, Draft Report to the Food and Nutrition Service of the United States Department of Agricutlure, May 1992.

Lazere, Edward, Paul Leanard, Cushing Dolbeare, and Barry Zigas. $\underline{A}$ Place to Call Home: The Low Income Housing Crisis Continues, Washington D.C.: The Center on Budget and Policy Priorities, December 1991.

Mallar, Charles. "The Educational and Labor Supply Responses of Young Adults on the Urban Graduated Work Incentive Experiment, " The New Jersey Income Maintenance Experiments, Harold Watts and Albert Rees (eds), New York: Academic Press, 1977.

Massachusetts Dept. of Health, Division of Family Services. 1983 Massachusetts Nutrition Survey, Department of Health: Boston, October 1983 .

Maynard, Rebecca and David Crawford. "School Performance," Rural Income Maintenance Experiment: Final Report, Madison WI: Institute for Research on Poverty, 1976.

Maynard, Rebecca and Richard Murnane. "The Effects of a Negative Income Tax on School Performance: Results of an Experiment," The Journal of Human Resources, XIV \#4, 1979.

McKey, Ruth et al. The Impact of Head Start on Children, Families and Communities: Final Report of the Head Start Evaluation, Synthes is and Utilization Project, Washington, D.C.: CSR, Incorporated, 1985.

Metcoff, Jack et al. "Effect of Food Supplementation (WIC) During Pregnancy on Birth Weight." The American Journal of Clinical Nutrition, 41, May 1985.

Meyers, Alan, Amy Sampson, Michael Weitzman and Herb Kayne. "School Breakfast Program and School Performance," American Journal of Diseases of Children, 143 \#N10, October 1989, $\frac{1234-1239 .}{123}$

Meyers, Alan et al. "Public Housing Subsidies May Improve Poor Children's Nutrition," American Journal of Public Health, 83\#1, January 1993.

Michael, Robert. "The Consumption Studies," in Welfare in Rural Areas: The Iowa Income Maintenance Experiment, John Palmer and Joseph Pechman (eds.), The Brookings Institution: Washington D.C., 1978.

Mitchell Janet and Rachel Shurman. "Access to Private Obstetrics/Gynecology Services Under Medicaid," Medical Care, 22, 
November 1984, 1026-1037.

Moffitt, Robert. "Incentive Effects of the U.S. Welfare System: A Review", Journal of Economic Literature, 30, March 1992, 1-61.

Moffitt, Robert. "Estimating the Value of an In-Kind Transfer: The Case of Food Stamps", Econometrica, 57 \#2, March 1989 385-410.

Moore, Kristin and Steven Caldwell. "The Effect of Government Policies on Out-of-Wedlock Sex and Pregnancy", Family Planning Perspectives, 9 \#4, July/August 1977, 164-169.

Mulroy, Elizabeth. "The Search for Affordable Housing," in women as Single Parents: Confronting the Institutional Barriers in the Courts, the Workplace and the Housing Market, E. Mulroy (ed.), New York: Auburn House, 1988.

Murray, Charles. Losing Ground, New York: Basic Books, 1984.

Newhouse, Joseph. "Medical Care Costs: How Much Welfare Loss?", Journal of Economic Perspectives, 6 \#3, Summer 1992, 3-22.

O'Conner, Frank, Patrick Madden, and Allen Prindle, "Nutrition," Rural Income Maintenance Experiment: Final Report, Madison WI: Institute for Research on Poverty, 1976.

Pedone, Carla. Current Housing Problems and Possible Federal Responses, Washington D.C.: Congressional Budget office, 1988.

Radzikowski, Jack and Steven Gale. "Requirement for the National Evaluation of School Nutrition Programs," The American Journal of Clinical Nutrition, 40, August 1984a, 365-367.

Radzikowski, Jack and Steven Gale. "The National Evaluation of School Nutrition Programs: Conclusions," The American Journal of Clinical Nutrition, 40, August $1984 \mathrm{~b}, 454-461$.

Robins, Philip. "A Comparison of the Labor Supply Findings from the Four Negative Income Tax Experiments, "Journal of Human Resources, 20 \#4, 1985, 567-582.

Rosenbaum, James, L.S. Rubinowitz, and M.J. Kulieke. Low Income African-American Children in White Suburban Schools, Evanston IL: Center for Urban Affairs and Policy Research, Northwestern University, 1986.

Rosenbaum, James. "Black Pioneers-Do Their Moves to the Suburbs Increase Economic Opportunity for Mothers and Children?, " Housing Policy Debate, 2 \#, 1992, 1179-1213.

Schramm, Wayne. "WIC Prenatal Participation and its Relationship to Newborn Medicaid Costs in Missouri: A Cost/Benefit Analysis." 
American Journal of Public Health, 75 \#8, August 1985.

Starfield, Barbara. Effectiveness of Medical Care: Validating Clinical Wisdom, Baltimore: Johns Hopkins University Press, 1985.

Stewart, Anne. Head Start: Funding Eligibility, and Participation, CRS Report for Congress, July 22, 1992 .

Thomas, Duncan. "Like Father Like Son, Or, Like Mother Like Daughter: Parental Education and Child Health," forthcoming Journal of Human Resources, 1993.

U.S. Department of Health and Human Services, Vital Statistics of the United States: Natality, various years.

U.S. Department of Health and Human Services, Centers for Disease Control, Public Health Service, CDC Analysis of Nutritional Indices for Selected WIC Participants, FNS-176, June 1978.

U.S. House of Representatives, Committee on Ways and Means. Overview of Entitlement Programs: 1992 Green Book, washington D.C.: U.S. Government Printing office, May 15, 1992 .

U.S. House of Representatives Committee on Ways and Means. 1991 Green Book: Backqround Material and Data on Programs within the Jurisdiction of the Committee on ways and Means, WMCP-102-9, washington D.C.: U.S. Government Printing Office, May 1991.

Venti, Steven. "The Effects of Income Maintenance on Work, Schooling, and Non-Market Activities of Youth," Review of Economics and Statistics, February 1984, 66 \#1, 16-25.

Zimmerman, David and Phillip Levine. "The Intergenerational Correlation in AFDC Participation: Welfare Trap or Poverty Trap", williams College mimeo, April 1993. 
</ref_section> 


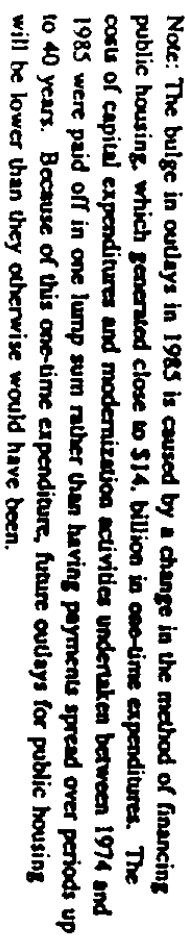

Bllions of 1990 dollars

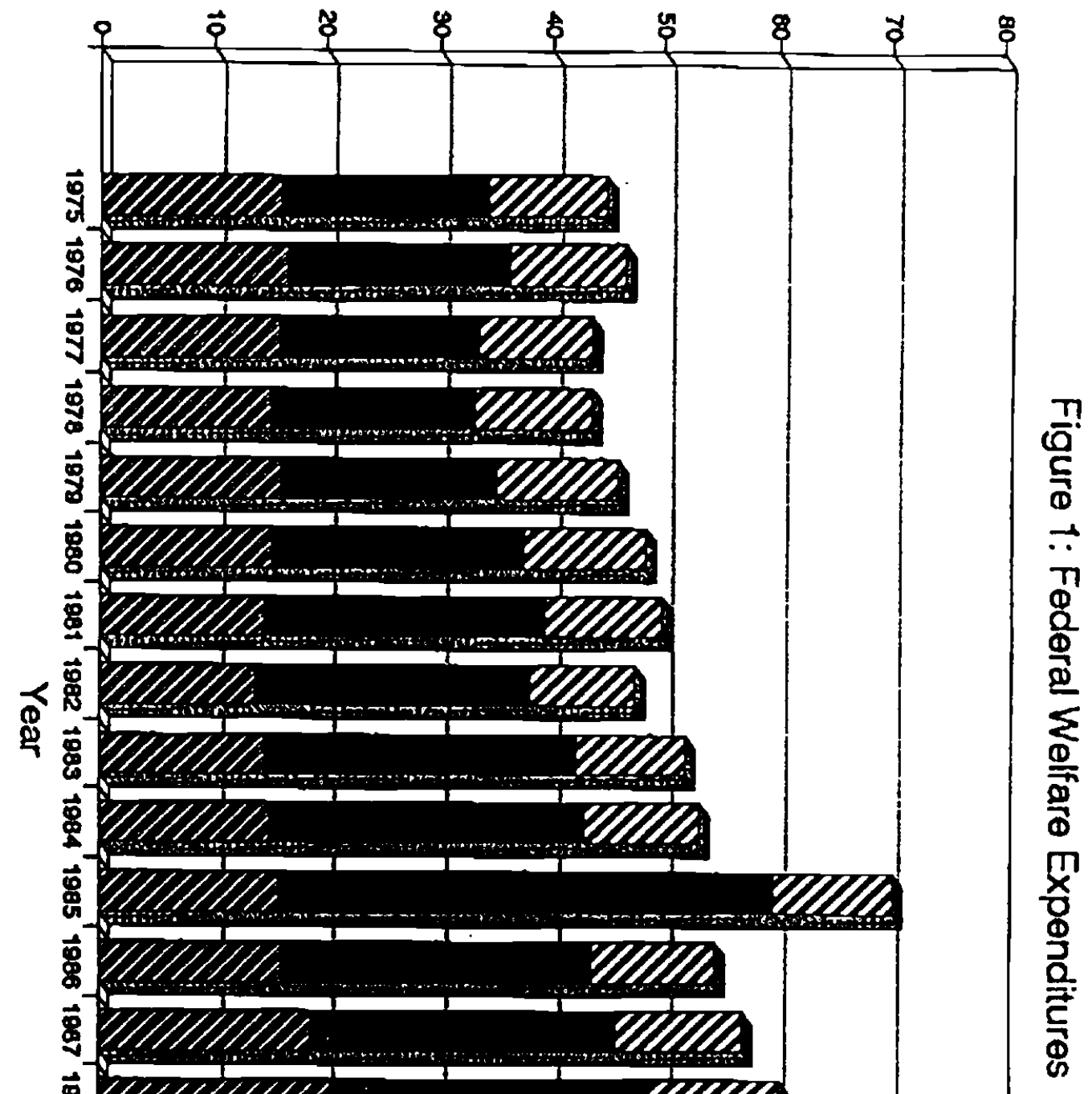



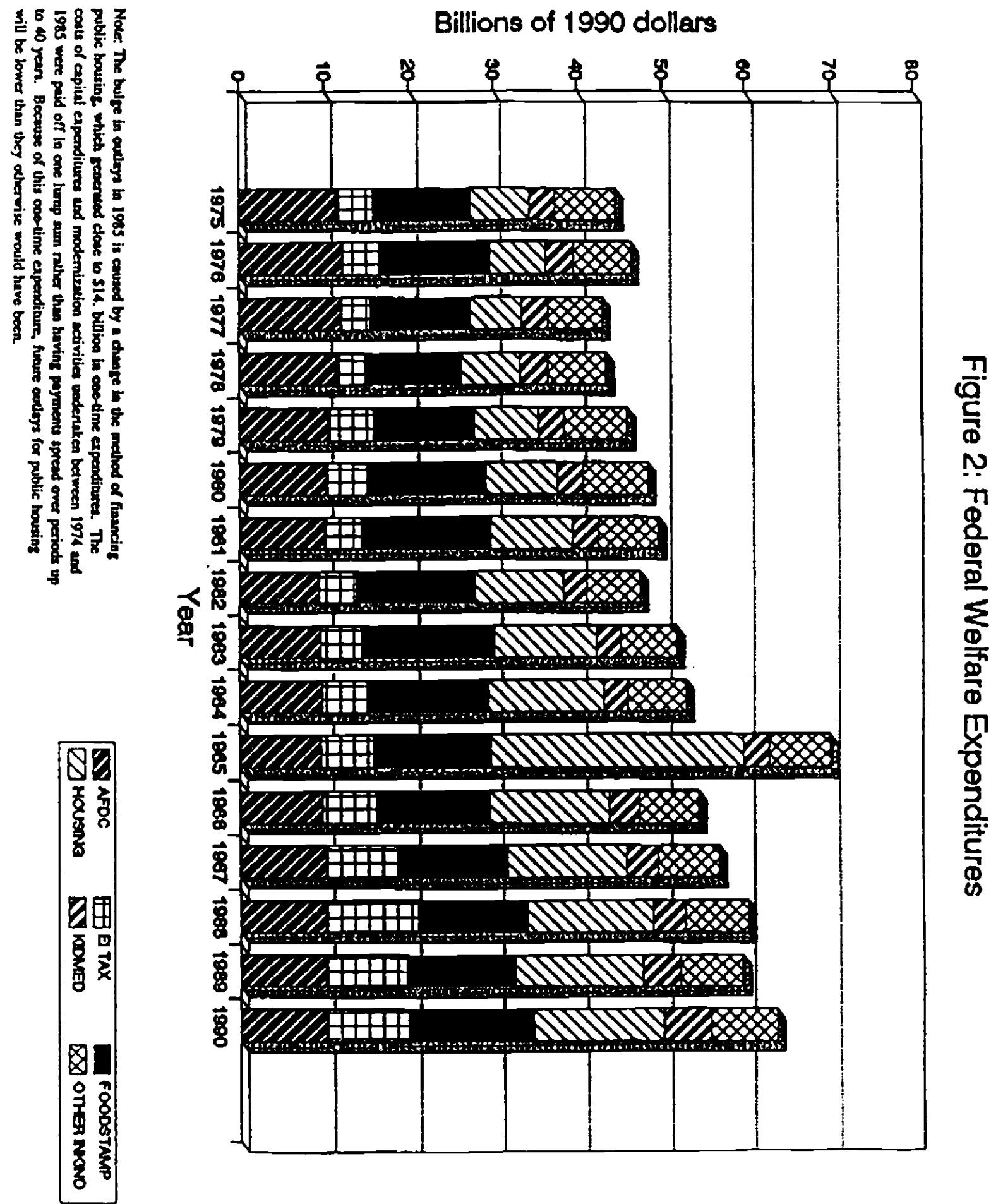


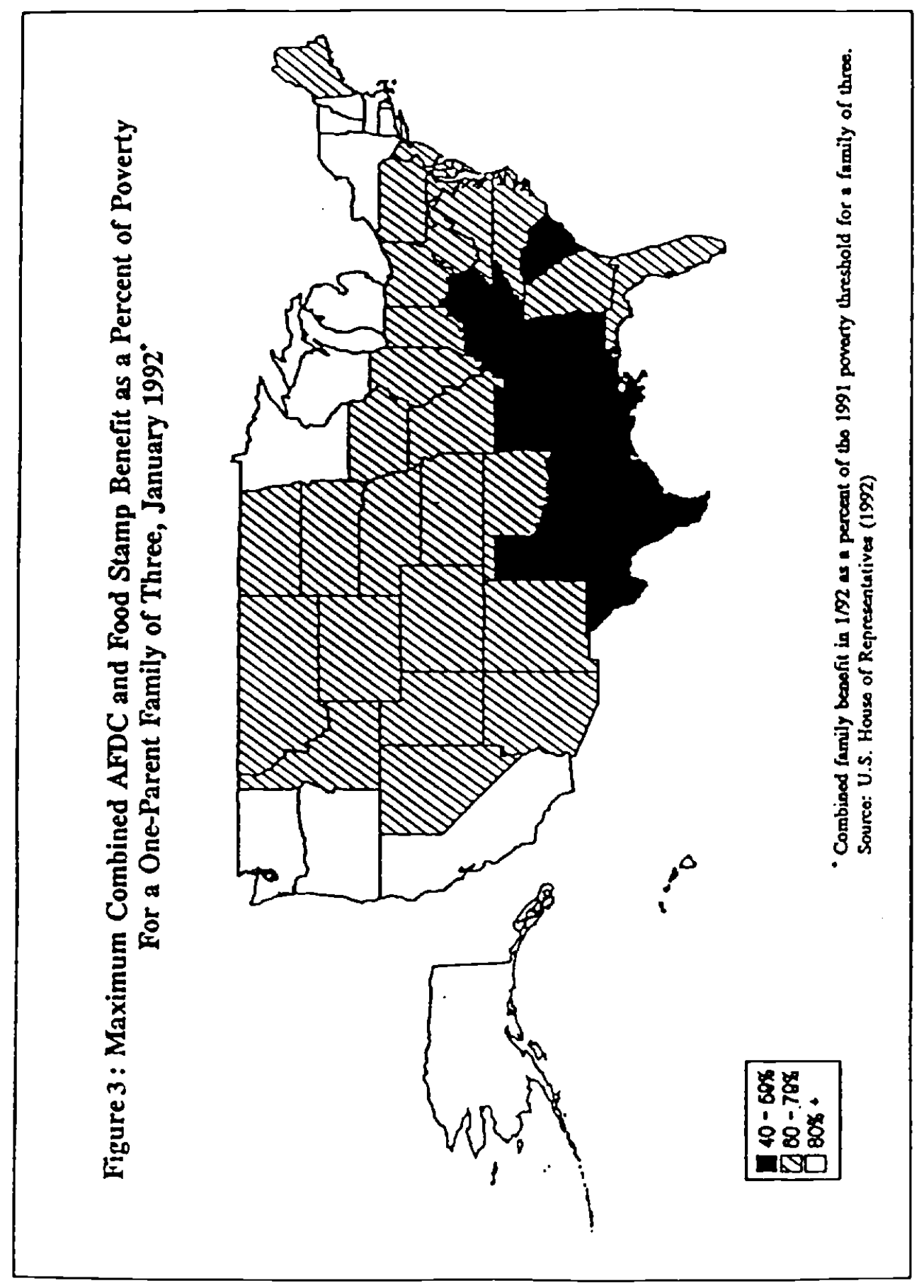



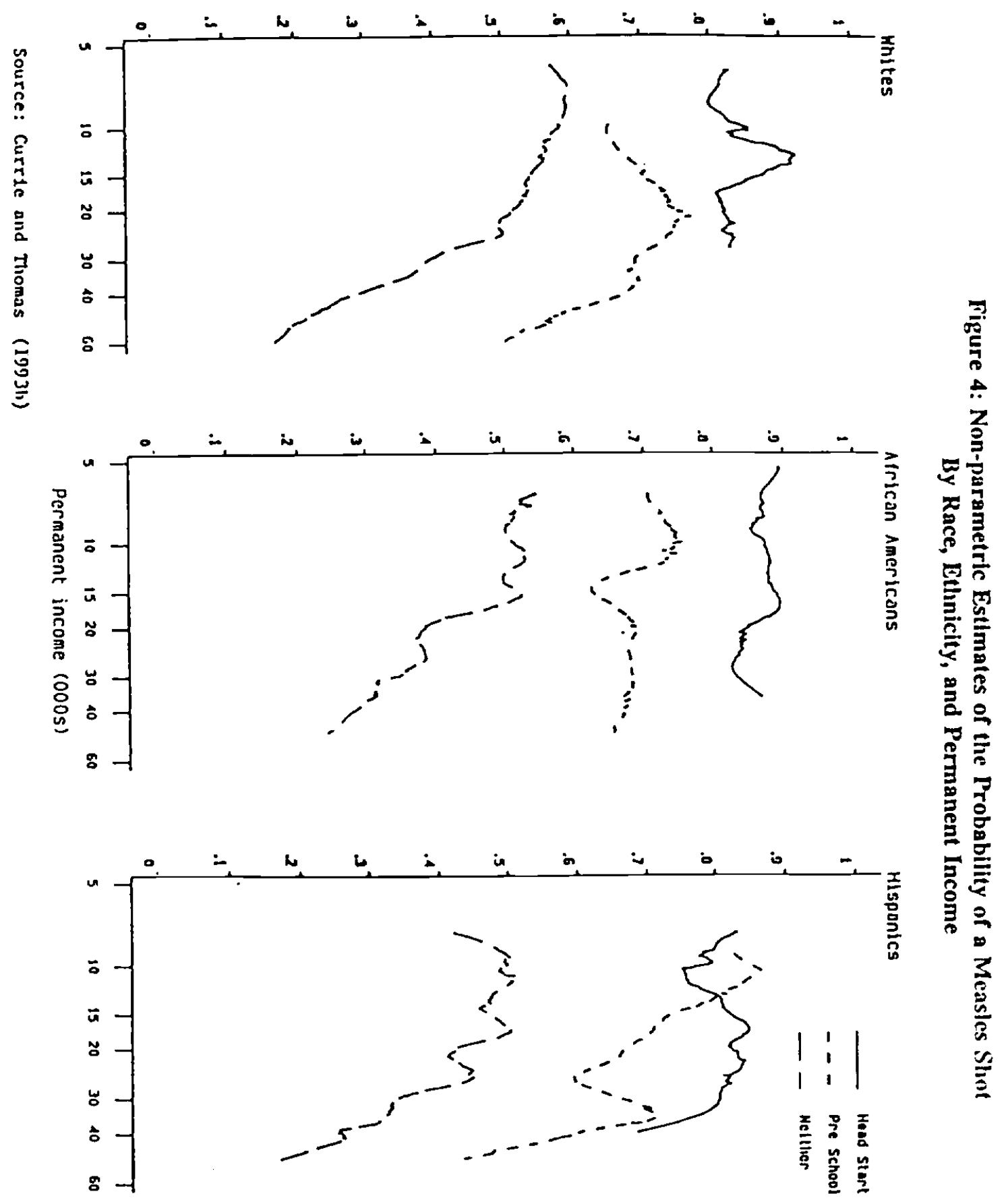